\title{
Does the SME Exchange Properly Function as a "Growth Market"? A Look Through its Correlation with Private-Firm Growth ${ }^{*}$
}

\author{
Hee Jung Choi, Deputy Research Fellow, National Pension Services - NPRI \\ Dong Wook Lee, ${ }^{* *}$ Professor, Korea University
}

\begin{abstract}
$<$ Abstract $>$
This paper evaluates whether a stock exchange targeted specifically at SMEs, namely, the SME exchange, functions as a "growth market" by capitalizing industry growth opportunities into stock prices. To this end, we examine the correlation between the SME exchange prices-aggregated up to the industry level-and private-firm growth. That is, we use the growth of private firms in an industry as a proxy for industry growth options that the SME exchange prices need to embody. Using data from Korea whose SME exchange is one of the largest in the world, we find that the SME exchange prices are positively correlated with the growth of private firms, especially when they are small in size, they belong to a growing industry, or their growth is funded by equity. In the same regression, the main board stock prices are correlated with the liability-funded growth of large-size private firms in a mature industry. Taken together, our results suggest that the SME exchange plays a positive and complementary role in the economy by embodying the type of industry growth opportunities that are not readily represented by the main board stock prices.
\end{abstract}

Keywords : SME Exchange; Private Firms; Industry; Growth Opportunities; Korea JEL Classification: G14, G31, G32

* We thank two anonymous referees, Eunyoung Cho, Ji-woong Chung, Joon Ho Hwang, Hyun Joong Im, Hyung Cheol Kang, Sang Koo Kang, Hyun Dong Kim, Woochan Kim, Kyung Suh Park, Jin Hyuk Ra, and the seminar participants and discussants at Korea University, the 2017 Allied Korean Finance Associations Conference, the 2017 Financial Management Association Conference, and the 2018 Korean Finance Association Conference (autumn) for comments. The earlier versions of the paper were circulated under the titles of "Stock prices of public firms and their spillovers on privately held companies: Evidence of negative externalities" and "Small-size public companies and industry aggregate fluctuations." The paper is in part based on the Ph.D. dissertation of Hee Jung Choi, Dong Wook Lee recognizes financial support from the Asian Institute of Corporate Governance (AICG) at Korea University. Dong Wook Lee is also grateful for the Korea University Business School Research Grant. This paper is supported by the Ministry of Education of the Republic of Korea and the National Research Foundation of Korea (NRF-2015S1A5A2A01013715).

** Corresponding Author. Address: Korea University Business School, 145, Anam-ro, Seongbuk-gu, Seoul, Korea, 02841; E-mail: donglee@korea.ac.kr; Tel: + 82-2-3290-2820; Fax: +82-2-3290-5394.

Received 12 February 2019; Revised 08 June 2019; Accepted 05 July 2019 


\section{Introduction}

Small and medium-size enterprises (SMEs) are consistently recognized as the engine for economic growth and as the source of creative and innovative activities (e.g., Ayyagari et al., 2011). However, SMEs have limited access to capital due to various market frictions, and hence a number of policy efforts have been made to ease their financial constraints (e.g., Beck and Demirguc-Kunt, 2006; Ayyagari et al., 2007). A good case in point is a separate stock exchange targeted specifically at SMEs, often called the SME exchange, which adopts less stringent listing requirements in order to accommodate SMEs' financing needs (e.g., World Federation of Exchanges, 2016; WFE hereafter). Unfortunately, the very nature of the SME exchange opens up the possibility that the prudence of public equity markets is compromised. That is, the SME exchange could add "noise" to capital markets by lowering the bar for companies' public-market presence and letting low-quality companies, and investors who speculate on them, taint the stock market.

Yet, any SME exchange aimed at being a "growth market" would engage companies in fast-growing and innovative sectors and, in doing so, would see itself becoming a place where uncertainties abound and investors with substantial risk appetites dominate. Thus, the speculative nature of an SME exchange is, in a sense, inevitable and cannot be the grounds for judging the exchange. Nor can the exchange's listing and capital-raising activities, as they could be driven by market frenzies. What seems to be a sensible approach to evaluating an SME exchange and its role in the economy-which we take in this paper-is to examine the exchange's stock prices. Specifically, one can evaluate the SME exchange by examining whether its prices represent the economic fundamentals of up-and-coming industries. A sectoral focus is quite typical of the growth-fostering programs in many countries and the SME exchange as a growth market is expected to identify promising sectors in the economy and capitalize their economic fundamentals—i.e., industry growth opportunities—into stock prices.

To operationalize this idea, we examine the correlation between the SME exchange stock prices-aggregated to the industry level—and the growth of the industry's privately held firms, in the spirit of the standard q theory in which the q ratio is a scaled stock price measure working as a sufficient statistic for investment (Tobin, 1969; Hayashi, 1982).1 ${ }^{1}$ In this approach, the growth of private firms in an industry serves as a proxy for the industry growth options that the SME exchange prices are expected to embody.

1) While there is a debate whether q alone is a sufficient statistic or it needs to be augmented by cash flow, it is indisputable that the stock price in the form of a $\mathrm{q}$ ratio contains information about corporate investment and growth opportunities (See, e.g., Fazzari et al., 1988; Kaplan and Zingales, 2000; Abel and Eberly, 2011). 
It is because those private firms are precisely the type of companies for which the SME exchange wants to make itself relevant as future listings. A positive correlation will then arise if-and only if - the prices contain relevant industry-level economic fundamentals. That is, the correlation with private-firm growth can be a barometer of how well or poorly the SME exchange prices-aggregated to the industry level and in the form of a q ratio-represent industry growth and investment opportunities.

Our analysis thus requires data for private firms as well as an SME exchange. In that regard, Korea stands out from a handful of possible experimental settings. By law, all companies in the country meeting certain criteria are subject to external auditing, regardless of whether they are privately held or publicly traded. As a result, a larger number of private companies have audited financial statements available. Korea also has an SME exchange, the KOSDAQ, that epitomizes both the pros and cons of such a listing venue, thereby constituting a useful case study.2) More specifically, the exchange is one of the most frequently cited examples of a successful SME exchange by outside observes, but among Korean investors, it is a byword for excessive volatility, speculation by individual investors, and dubious corporate data. ${ }^{3)}$ Using data from Korea, we show that the SME exchange stock prices embody the type of industry growth opportunities that are not readily captured by the main board stock prices.

Before detailing the results, we stress that we do not seek a causal relation between the SME exchange prices and private-firm growth. Our goal in this paper is to understand how well the industry-level growth opportunities-i.e., those that are relevant to private firms as well as to the exchange-listed companies in the same industry-are incorporated into the prices of the SME exchange. Our analysis is thus premised only on the shared economic fundamentals between publicly-traded companies and privately-held ones. A causal relationship between the two groups of companies, possibly via public-market stock prices, is certainly conceivable or even likely. Such causality, however, would only strengthen our premise, because causality-if any were found-stems from shared economic fundamentals (e.g., Morck and Yeung, 2011).

For the period of 1999 to 2015, we find that the SME exchange stock price, as measured by the Tobin's q ratio averaged over the SME exchange-listed companies within an industry, is positively related to the growth of private firms in the same industry. This correlation is obtained from a regression where the main board stock price, similarly measured by the q ratio averaged over the main board-listed companies within industry, is present. While both exchanges' q ratios are statistically sig-

2) The main board in Korea is called KOSPI. To avoid confusion, we use the term "main board" to refer to KOSPI, and continue to use the term "SME exchange" for KOSDAQ.

3) See, for example, WFE (2016) for the positive aspects of the Korean SME exchange. In Section 2, we also provide the exchange's institutional details. 
nificant in relation to private-firm growth, the economic significance of the SMEexchange $q$ is greater than that of the main-board $q$. When we employ the marketwide q ratios, as measured by the Tobin's q averaged over all SME exchange-listed or all main board-listed companies across industries, in lieu of year fixed effects, the market $q$ of the main board is positively related to private-firm growth but the market $q$ of the SME exchange is not. In this specification, the industry-specific q of the SME exchange remains significantly positive and its greater economic significance compared to that of the main-board industry $q$ is even more pronounced. From this result, we infer that the SME exchange capitalizes industry-specific growth opportunities into its prices, whereas the main-board stock prices represent market-wide growth options. In other words, the two exchanges are complementary to each other in terms of capitalizing aggregate-level economic fundamentals.

As the SME exchange is aimed specifically at small to medium-size companies, the industry growth opportunities reflected in the exchange's prices should be relevant more to smaller-size private firms than to larger ones. In fact, some private companies in Korea are big enough to list their shares on the main board but they choose to remain private. Moreover, most of those large-size private companies are associated with a major business group and thus do not qualify as the type of firms whose growth options are expected to be present in the SME exchange prices. Firm size is thus a useful dimension in which to further examine the correlation between the SME exchange prices and private-firm growth. The other instructive dimension is industry growth, because the ultimate question here is whether the SME exchange recognizes sector-wide growth potentials and capitalizes them into its stock prices. We thus expect the SME exchange prices to be informative, in particular, about the economic fundamentals of growing industries.

It turns out that the correlation between the SME-exchange industry $q$ and private-firm growth is more pronounced when the private firm is smaller in size than when it is larger, and when the private firm belongs to a growing industry rather than to a mature one. On the contrary, the correlation between the main-board industry $q$ and private-firm growth is stronger in the larger-firm sub-sample than in the smaller-firm sub-sample, and in the mature-industry sub-sample than in the growing-industry sub-sample. Across the sub-samples sorted independently by firm size and industry growth, the SME-exchange industry q is correlated with the growth of both small and large private firms, as long as they belong to a growing industry. However, the economic significance is twice as large in the small-firm sub-sample as in the large-firm sub-sample. For the main-board industry q, an exact opposite pattern exists: the main-board industry $q$ is related to the growth of both smaller-size and larger companies, provided that those companies belong to a mature industry. 
Besides firm size and industry growth, funding source is another useful angle of the correlation. As the SME exchange itself is an effort to diversify SMEs' funding sources beyond debt, we would expect the exchange prices to be informative about the market conditions for non-debt financing options as well as for debt. Of those nondebt financing options, equity is particularly suitable for the type of innovative yet high-risk investments that SMEs are expected to take in the economy. We thus predict the industry-level growth opportunities reflected in the SME exchange pricesi.e., those that are driving the correlation between the exchange's industry $q$ and private-firm growth - to be most pronounced when the growth is funded by equity. Consistent with this prediction, we find that the SME-exchange industry $q$ is most highly correlated with the equity-financed growth of private firms. While the SME-exchange $\mathrm{q}$ is correlated with other types of funding-e.g., debt and non-debt liabilities, the greater economic significance of the SME-exchange q compared to the main-board $q$ is most pronounced when private-firm growth is funded by equity. Combined with the dimensions of firm size and industry growth, the SME-exchange industry $q$ is most highly correlated with the equity-funded growth of small-size private companies particularly when the private firm is a member of a growing industry.

A concern about the observed correlation is that it might be driven by "common noise." Industry-wide misinformation could be at work both in the SME-exchange stock prices and in the minds of private-firm managers, thereby causing noise in the SME-exchange q ratio and ill-informed decisions by private firms in the same direction as the noise.4) One way of gauging the role of such common noise in the observed correlation is to examine whether the correlation is subsequently reversed; laterrevealed economic fundamentals would challenge any earlier-made decisions that turn out to be ill-informed. On these grounds, we lead the dependent variable of our regressions-i.e., private-firm growth-by one or two years and examine whether it is negatively correlated with the SME-exchange industry q. We find little support for this prediction; particularly with small-size private firms and those in growing industries, for which we find a significantly positive contemporaneous correlation, we find no sign of reversal.

Another empirical implication stemming from the common noise scenario is aggregate volatility. To the extent that industry-wide misinformation is at work, companies under its influence would comove, giving rise to aggregate volatility. When subsequently the misinformation is proven wrong, companies under its initial influence will again comove, as the impact of the earlier misinformation is undone, and the ag-

4) It could be that some noise in the SME-exchange $q$ misleads private firms to (not) invest. As stressed earlier, however, our analysis encompasses - but is not limited to-such causality. 
gregate volatility will rise again. Unlike the earlier correlation analyses, however, the industry q ratio-i.e., the Tobin's q averaged over the SME exchange-listed firms within industry - cannot be used to test this prediction. It is because both high and low q ratios can lead to comovement among private firms, making it unclear how to judge whether a given level of $q$ is too high or too low. As an alternative, we utilize the number of SME-exchange listings from an industry. The idea is that this measure quantifies the extent to which a given noise is diversified away (if it is firm-specific) or solidified (if it is industry-wide) in the average q ratio, which drives our earlier correlation results. Thus, by associating it with the comovement of private firms and their aggregate volatility, we can gauge the existence of industry-wide misinformation and its impact on our earlier results.

We begin this analysis by regressing the cross-sectional dispersion of private-firm growth within industry on the log number of the SME exchange listings and control variables. We find that the dispersion is negatively associated with the SME exchange listings, although the results are somewhat sensitive to regression specifications. Alternatively, when we regress the aggregate volatility of private-firm growth on the log number of the SME-exchange listings along with control variables, we find no positive relation between the two. All in all, the evidence of common noise playing a role in our earlier correlation results seems weak at best.

Not really about economic fundamentals versus noise, some may say. They may even go on to say that our results are trivial because they all stem from comovement among private firms, which should be stronger when those private firms are small in size or when they belong to a growing industry. Indeed, it is highly likely that smallsize companies are particularly vulnerable to aggregate market and industry swings and thus move together in accordance with those aggregate-level conditions. It is also exceedingly plausible — and almost tautological to say — that growing industries have strong industry-wide fundamentals and thus companies in those industries move together within industry. In short, the criticism is that our paper is showing nothing but the obvious: the SME exchange prices reflect those industry-wide conditions.

Our response to the criticism is, that is exactly what we want to show in this paper. Recall that our analysis is designed specifically to examine whether those industrywide conditions are better reflected in the SME exchange prices than in the main board prices. In other words, our goal is to see whether the SME exchange is redundant or if it plays a unique role in terms of capitalizing aggregate-level-especially industry-level-economic fundamentals and growth opportunities. Indeed, our paper is showing that, by capitalizing the type of industry growth opportunities that are relevant to small-size private firms and those in growing industries especially when 
they fund their growth via equity, the SME exchange is augmenting the main board and is serving as a growth market.

At least two literatures are related to our paper. First, the paper adds to the literature on SME exchanges. As noted by Alderighi et al. (2017), studies on SME exchanges are few and only a handful of papers provide empirical results-mostly mixed-by directly examining the companies listed on the exchange (e.g., Carpentier et al., 2010, 2012; Gerakos et al., 2013). To this, we add two things. One is that we propose a new approach to evaluating an SME exchange, namely, examining the informativeness of the SME exchange prices about industry growth opportunities by looking at their correlation with the growth of private firms in the same industry. The other is that we provide empirical evidence that the SME exchange in Koreaone of the largest and most cited SME exchanges in the world-functions as a growth market by capitalizing industry growth opportunities into its prices.

Second, our paper contributes to the growing literature on private firms (e.g., Asker et al., 2012, 2015; Badertscher et al., 2013; Badertscher et al., 2017). Specifically, we show that private firms' relation with public companies can differ depending on the listing venues of the latter group of companies. To be more precise, private firms share industry-specific factors mostly with SME exchange-listed companies, and the commonalities between private firms and main board-listed companies are attributable largely to market-wide factors. Thus, our paper suggests that studies on private firms and their commonalities should take the within-industry comovement as seriously as the market-wide one.

This paper proceeds as follows. Section 2 describes the sample and data. Sections 3 examines the correlation between the SME exchange stock prices and private-firm growth, in comparison with the correlation between the main board stock prices and private-firm growth. Section 4 examines the correlation by funding sources of privatefirm growth and Section 5 conducts additional robustness checks. Section 6 concludes the paper.

\section{Sample and Data}

To construct the sample, we begin with all firms covered by FnGuide, a Korean database covering both public and private companies. Financial data for private companies are made available by the Korean law that requires companies meeting certain criteria to be audited externally. One of the criteria is firm size and, at the time when this paper is written, the size cutoff is 12 billion Korean wons (approximately 11 million U.S. dollars). 
We drop the firm-year observations whose total assets are missing or negative during the 1999 2015 period. We also drop the firm-year observations when the company goes public. We further screen the sample by dropping firms with no corporation identification code, firms whose industry classification is missing, and firms whose industry code is " $\mathrm{K}$ " (financials \& insurance companies), "O" (Public administration, national defense, \& social security administration), or " $Q$ " (Public health \& social welfare). After those screenings, we obtain 240,401 firm-year observations. Of those firm-year observations, approximately 90\% $(217,398)$ are private firms. We further require a private firm to have at least one public industry peer, with industry defined by the 3-digit Korean SIC codes. This requirement reduces the private-firm observations down to 200,631. During the sample period, 34,726 private firms enter the sample at least once and the sample contains 1,437 unique public firms. There are 144 unique industries defined by the 3-digit SIC codes.

$<$ Table $1>$ describes our final sample. The first row shows that, in a given year, our sample consists of a much larger number of private firms than publicly traded companies. About $90 \%$ of the sample firms in a given year are privately held, as is the case with the full firm-year panel. When we further separate public firms by their listed exchange into the main board and the SME exchange, the SME exchange houses a larger number of companies than the main board (808 vs. 629).5) The second and third rows show that private firms are much smaller than public companies. The average asset size of a private firm is about one tenth of a public firm (one fifth by median). Due to the larger number in the economy, however, private firms as a whole

\section{$\langle$ Table 1〉 Sample Firms}

The table compares sample private and public companies in Korea in terms of the number of firms, firm size, and investment. Our sample is obtained by a series of data screens, which are detailed in Section 2. The sample period is from 1999 to 2015.

\begin{tabular}{|c|c|c|c|c|c|}
\hline & \multirow{2}{*}{ Private } & \multirow{2}{*}{ Public } & \multicolumn{2}{|c|}{ Public firms by exchange } \\
\hline & & & & main board & SME exchange \\
\hline \multicolumn{2}{|c|}{ average number of firms } & 12,539 & 1,437 & 629 & 808 \\
\hline firm size & average & 61.7 & 696 & $1,482.2$ & 95.9 \\
\hline \multirow[t]{2}{*}{ (in billion KRWs) } & median & 19.8 & 95.6 & 247.2 & 59.5 \\
\hline & aggregate & 808,217 & $1,027,330$ & 946,259 & 81,071 \\
\hline \multirow{3}{*}{$\begin{array}{l}\text { annual asset growth } \\
\text { (in billion KRWs) }\end{array}$} & average & 3.1 & 37.2 & 78.8 & 5.5 \\
\hline & median & 0.3 & 2.6 & 5 & 1.8 \\
\hline & aggregate & 39,880 & 54,442 & 50,105 & 4,337 \\
\hline
\end{tabular}

5) There are a handful of migrations from the SME exchange to the main board. According to Binh et al (2016), there are 38 migration events for the period from January 1999 to April 2010. We treat those migrating firms as main board-listed, so that the SME exchange stock prices in our analysis are free from any anticipation effects. 
are comparable to public firms (fourth row): the assets under the management of private firms are worth more than 808 trillion Korean wons (KRWs), whereas the value of assets managed by public firms is 1,027 trillion KRWs. Similar statements can be made for asset growth. While a given private firm grows in a smaller scale than a typical public firm (3.8 billion KRWs vs. 37 billion KRWs), the aggregate growth of private firms is comparable to that of public firms as a whole (39 trillion KRWs vs. 54 trillion KRWs).

While not tabulated, industry distribution in our sample is not so different between private and public firms. Except for the real estate management sector that is almost entirely composed of private firms, other sectors are populated by both private and public companies. The majority of private and public firms are in the manufacturing sector (industry sector code "C"), followed by the service sector.6) In terms of the number of companies, the two sectors combined account for more than $80 \%$ of the sample private firms and over $90 \%$ of the sample public firms. Not surprisingly, however, there is a compositional difference between the SME exchange and the main board. Industries related to information, communication, or bio technologies have a larger presence in the SME exchange (42\%) than in the main board (16\%).

As mentioned in the introduction, the Korea SME exchange is one of the most "well-functioning" SME exchanges in the world. For example, the World Federation of Exchanges reports that, in 2016, the listings in KOSDAQ are outnumbered only by those in TSX Venture of Canada. During that year, the Korean SME exchange hosted 71 new lists and ranks second only to China's ChiNext (72 new lists), and is also placed third in terms of the capital raised, after the NYSE MKT in the U.S. (formerly AMEX) and ChiNext.7) In stark contrast, the perception of the SME exchange in the field is far from being positive. As one illustration, academics in the country regularly exclude the SME exchange-listed stocks from their empirical analysis (e.g., Jung et al., 2009). This characterization of the SME exchange in Korea, however, should not be attributed to market microstructure issues, as the main board and the SME exchange in Korea employ the same trading mechanism. The two exchanges also have the same owner and are monitored by the same regulatory authorities. The difference between the two exchanges stems only from the differing requirements for listings.

6) The service sector is defined passively by excluding agriculture, forestry, and fishing ("A"), manufacturing ("C"), construction ("F"), and transportation ("H"). More than a quarter of the service sector is from the retail and wholesale industry ("G").

7) Source: https://www.world-exchanges.org/home/index.php/statistics/annual-statistics. 


\section{Correlation between SME Exchange Prices and Private-Firm Growth}

\subsection{Main Results}

In order to examine the correlation between the stock prices of SME exchange and the growth of privately held SMEs, we estimate the following base-line equation:

$$
\Delta A_{i, t}=c f_{i, t-1}+\ln \left(A_{i, t-1}\right)+q_{\text {peer }, t-1}+c f_{\text {peer }, t-1}+\ln \left(A_{\text {peer }, t-1}\right)+f_{i}+y_{t}+\varepsilon_{i, t},
$$

where $\Delta A_{i, t}$ is the total asset growth rate of private firm $i$ during year $t, c f_{i, t-1}$ is the cash flow (i.e., operating income plus depreciation) of private firm $i$ at the end of year $t-1$, and $A_{i, t-1}$ is the total assets of private firm $i$ at the end of year $t-1$. The variables for "peer"-namely, $q_{\text {per }, t-1}, c f_{\text {per }, t-1}$, and $A_{\text {peer }, t-1}$ - are the equally weighted average values across SME exchange-listed (denoted by SME ind) or main boardlisted (denoted by MAIN ind) companies in the same industry as private firm $i$. Finally, $f$ and $y$ are, respectively, firm and year fixed effects. We explore several modifications of this baseline specification.

$<$ Table $2>$ reports the results. Regression (1) shows that the SME exchange q-i.e., the $q$ ratio that is averaged over the SME exchange-listed companies in the same industry as a given private firm -is positively related to the asset growth of the private firm. The positive coefficient means that the SME exchange prices represent the industry growth opportunities that are relevant to the growth of private firms. ${ }^{8)}$ Regression (2) adds another q ratio to Regression (1), namely, the across-the-board average of the SME exchange q's-denoted as $q_{S M E \text { mkt }}$-in lieu of the year fixed effects. The market-wide $q$ enters the regression with a significant and positive coefficient, but its economic significance is smaller than its industry-specific q. For example, a change in the industry-specific SME-exchange q by its own one standard deviation is associated with an asset growth of $1.8 \%$ (i.e., $0.0371 \times 0.476$ ), which is more than one fifth of the typical asset growth of a private firm (8.8\%). A one-standard-deviation change of the market-wide SME exchange $q$, on the other hand, is associated with an asset growth of $0.6 \%$ (i.e., $0.0233 \times 0.237$ ). It is thus just one third of the economic significance of the industry-specific $\mathrm{q}$.

Regressions (3) and (4) are the same as the first two specifications, except that the q ratio is computed with the main board-listed companies. Quite contrary to the SME exchange case, the correlation between the main-board $q$ and private-firm growth is more pronounced when the $q$ is a market-wide measure. Specifically, the economic significance of the main-board market $q$ is twice as large as that of the exchange's

8) Again, we stress that we are not particularly arguing that the SME exchange prices cause private firms to invest. 
industry $q(0.0220 \times 0.436$ for the main-board industry $q$ vs. $0.1561 \times 0.116$ for the main-board market q).

\section{〈Table 2〉 Panel Regressions of Private-Firm Growth on Public-Firm a}

The table reports firm-year panel regressions of the annual total-asset growth rate of private firms on the average q ratios of public firms and other control variables. The regressors are detailed in Section 3.1 (below Eq. (1)). Numbers in brackets are the cluster-robust standard errors. ${ }^{*},{ }^{* *}$, and ${ }^{* * *}$ indicate the statistical significance at the $10 \%, 5 \%$ and $1 \%$ levels, respectively.

\begin{tabular}{|c|c|c|c|c|c|c|}
\hline & \multicolumn{6}{|c|}{ dependent variable: annual asset growth rate of private firms } \\
\hline & (1) & (2) & (3) & (4) & (5) & (6) \\
\hline$c f_{i}$ & $\begin{array}{l}0.2996_{* * *} \\
{[0.015]}\end{array}$ & $\begin{array}{l}0.2810^{* * *} \\
{[0.014]}\end{array}$ & 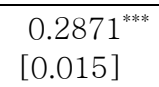 & $\begin{array}{l}0.2641^{* * *} \\
{[0.015]}\end{array}$ & $\begin{array}{l}0_{0.2929^{* * *}} \\
{[0.015]}\end{array}$ & $\begin{array}{l}0.2902^{* * *} \\
{[0.015]}\end{array}$ \\
\hline $\ln \left(A_{j}\right)$ & $\begin{array}{c}-0.3307^{* * *} \\
{[0.004]}\end{array}$ & $\begin{array}{c}-0.3221^{* * *} \\
{[0.004]}\end{array}$ & $\begin{array}{c}-0.3264^{* * *} \\
{[0.004]}\end{array}$ & $\begin{array}{c}-0.3152^{* * *} \\
{[0.004]}\end{array}$ & $\begin{array}{c}-0.3285^{* * *} \\
{[0.004]}\end{array}$ & $\begin{array}{c}-0.3303^{* * *} \\
{[0.004]}\end{array}$ \\
\hline$q_{S M E \text { ind }}$ & $\begin{array}{l}0.0290_{* * *} \\
{[0.003]}\end{array}$ & $\begin{array}{l}0.0371^{* * *} \\
{[0.003]}\end{array}$ & & & $\begin{array}{l}0.0202^{* * *} \\
{[0.003]}\end{array}$ & $\begin{array}{l}0.0222^{* * *} \\
{[0.003]}\end{array}$ \\
\hline$c f_{S M E}$ ind & $\begin{array}{r}-0.0227 \\
{[0.021]}\end{array}$ & $\begin{array}{c}-0.1432^{* * *} \\
{[0.020]}\end{array}$ & & & $\begin{array}{c}-0.0754^{* * *} \\
{[0.023]}\end{array}$ & $\begin{array}{c}-0.1100^{* * *} \\
{[0.023]}\end{array}$ \\
\hline $\ln \left(A_{S M E \text { ind }}\right)$ & $\begin{array}{l}0.0490_{* * *} \\
{[0.004]}\end{array}$ & $\begin{array}{l}0.0810^{* * *} \\
{[0.003]}\end{array}$ & & & $\begin{array}{l}0.0461^{* * *} \\
{[0.004]}\end{array}$ & $\begin{array}{l}0.0488^{* * *} \\
{[0.003]}\end{array}$ \\
\hline$q_{S M E \text { mkt }}$ & & $\begin{array}{l}0.0233^{* * *} \\
{[0.004]}\end{array}$ & & & & $\begin{array}{c}-0.0463^{* * *} \\
{[0.006]}\end{array}$ \\
\hline$q_{\text {MAIN ind }}$ & & & $\begin{array}{l}0.0225^{* * *} \\
{[0.003]}\end{array}$ & $\begin{array}{c}0.0220^{* * *} \\
{[0.003]}\end{array}$ & $\begin{array}{l}0.0159^{* * *} \\
{[0.003]}\end{array}$ & $\begin{array}{c}0.0154^{* * *} \\
{[0.003]}\end{array}$ \\
\hline$c f_{\text {MAIN ind }}$ & & & $\begin{array}{l}0.0514^{* * *} \\
{[0.018]}\end{array}$ & $\begin{array}{l}0.0572^{* * *} \\
{[0.018]}\end{array}$ & $\begin{array}{r}-0.0036 \\
{[0.019]}\end{array}$ & $\begin{array}{r}0.0252 \\
{[0.019]}\end{array}$ \\
\hline $\ln \left(A_{\text {MAIN ind }}\right)$ & & & $\begin{array}{l}0.0355^{* * *} \\
{[0.004]}\end{array}$ & $\begin{array}{c}0.0606^{* * *} \\
{[0.003]}\end{array}$ & $\begin{array}{l}0.0384^{* * *} \\
{[0.004]}\end{array}$ & $\begin{array}{l}0.0419^{* * *} \\
{[0.003]}\end{array}$ \\
\hline$q_{\text {MAIN mkt }}$ & & & & $\begin{array}{l}0.1561^{* * * *} \\
{[0.008]}\end{array}$ & & $\begin{array}{l}0.1809^{* * * *} \\
{[0.015]}\end{array}$ \\
\hline \# of obs & 192,751 & 192,751 & 186,476 & 186,476 & 178,596 & 178,596 \\
\hline$R^{2}$ & 0.179 & 0.170 & 0.177 & 0.169 & 0.177 & 0.171 \\
\hline \# of firms & 33,360 & 33,360 & 32,414 & 32,414 & 31,048 & 31,048 \\
\hline Firm FE & YES & YES & YES & YES & YES & YES \\
\hline Year FE & YES & NO & YES & $\mathrm{NO}$ & YES & $\mathrm{NO}$ \\
\hline
\end{tabular}

Regression (5) pits the SME exchange industry q against the main board industry q by including both in one regression. The result shows that the industry $q$ based on the SME exchange prices is economically more significant than the industry q of the main board. Specifically, the economic significance of the SME-exchange industry q is approximately $33 \%$ greater than that of the main-board industry $q(0.0202 \times 0.441=$ 0.00891 for the SME-exchange industry q vs. $0.0159 \times 0.422=0.00671$ for the mainboard industry q). 
Finally, Regression (6) includes all four q ratios-the industry q and the market $q$ based on the SME prices and the industry $q$ and the market $q$ based on the main board prices-in one regression. It turns out that the industry-specific q is most significant and positive when it is based on the SME exchange prices and the marketwide $q$ is most significant and positive when it is based on the main board prices. The two q ratios - with a change by one standard deviation of their own-are associated with the private-firm growth of $1 \%$ and $2 \%$, respectively. The interpretation is that it is certainly the market-wide factors that are most correlated with the growth of private firms and those factors are best represented by the main board stock prices. After controlling for this market-wide movement, there are industry-specific growth opportunities relevant to private firms and those industry growth opportunities are better captured by the SME exchange prices than by the main board prices.

One concern about Regression (6) is that the importance of the main-board industry q might be under-stated by the presence of the main-board market q. In the following analysis, we thus use Regression (5) as the main specification. As a summary of the main finding in Regression (5), <Figure $1>$ compares the economic significance of the SME-exchange industry $q$ and the main-board $q$, which is computed as a percent of the mean private-firm growth rate that is explained by the product of the estimated coefficient and its one standard deviation.

Besides the q-ratio, other regression variables carry the usual signs. Specifically, the coefficient for the own-cash flow is positive, while that of the own-size variable is negative. Those signs are typical of the q regression (e.g., Fazzari et al., 1988). Interestingly, the average cash flow of the SME exchange-listed firms is negative and sta-

\section{〈Figure 1〉 Economic Significance of Estimated Coefficients on Industry q ratio}

This figure shows the economic significance of the estimated coefficients on the SMEexchange industry q ratio and the main-board industry q ratio. Specifically, the coefficients are from Regression (5) of 〈Table 2〉 and the economic significance is compute as the fraction of the mean dependent variable that is associated with the estimated coefficient times its own standard deviation.

Economic significance as percent of mean private-firm growth

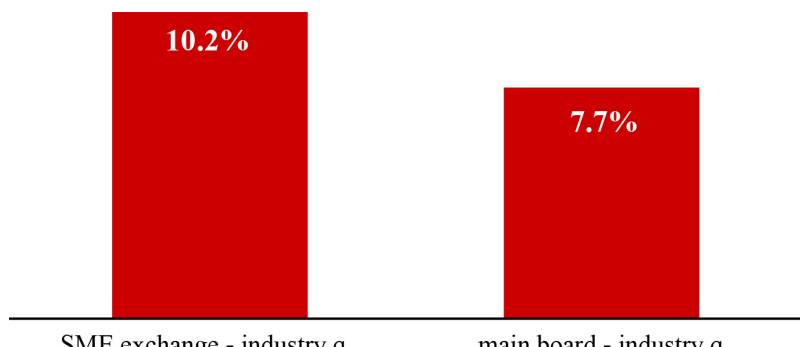

SME exchange - industry q

main board - industry $\mathrm{q}$ 
tistically significant in the presence of the market-wide q. We do not further pursue the meaning of the negative coefficient on the cash flow of the exchange-listed industry peers, since our focus is their q ratio.

\subsection{Sub-Sample Analysis}

To better understand the observed correlation between the SME-exchange industry $q$ and private-firm growth, we conduct sub-sample analysis. Specifically, we sort the sample by the size of private firms and by the growth profile of industries. By nature, the SME exchange prices are expected to represent the type of industry growth op-

〈Table 3〉 Panel Regressions of Private-Firm Growth on Public-Firm q - by Sub-Samples

The table reports firm-year panel regressions of the annual total-asset growth rate of private firms on the average q ratios of public firms and other control variables. Regressions are estimated within sub-samples sorted by private-firm size (small and large), by industry growth rate (low-, mid-, and high-growth), or by both. The regressors are the same as those in <Table 2>. Numbers in brackets are the cluster-robust standard errors. *, **, and ${ }^{* * *}$ indicate the statistical significance at the $10 \%, 5 \%$ and $1 \%$ levels, respectively.

Panel A: Sub-samples sorted by private firm size or industry growth rate

\begin{tabular}{|c|c|c|c|c|c|}
\hline & \multicolumn{5}{|c|}{ dependent variable: annual asset growth rate of private firms } \\
\hline & \multicolumn{2}{|c|}{ sort by private firm size } & \multicolumn{3}{|c|}{ sort by industry growth rate } \\
\hline & small & large & $\begin{array}{c}\text { low growth in- } \\
\text { dustries }\end{array}$ & $\begin{array}{l}\text { mid-growth in- } \\
\text { dustries }\end{array}$ & $\begin{array}{l}\text { high-growth } \\
\text { industries }\end{array}$ \\
\hline \multirow[t]{2}{*}{$c f_{i}$} & $0.3708^{* * *}$ & $0.2609^{* * *}$ & $0.1123^{* * *}$ & $0.3999^{* * *}$ & $0.4262^{\text {**** }}$ \\
\hline & {$[0.021]$} & {$[0.021]$} & [0.028] & {$[0.023]$} & {$[0.025]$} \\
\hline \multirow[t]{2}{*}{$\ln \left(A_{i}\right)$} & $-0.5583^{* * *}$ & $-0.2864^{* * *}$ & $-0.3408^{* * *}$ & $-0.3232^{* * *}$ & $-0.3362^{* * *}$ \\
\hline & {$[0.010]$} & {$[0.006]$} & [0.007] & {$[0.007]$} & {$[0.008]$} \\
\hline \multirow{2}{*}{$q_{S M E}$ ind } & $0.0237^{* * *}$ & $0.0133^{* * *}$ & -0.0020 & $0.0155^{* * *}$ & $0.0479^{* * *}$ \\
\hline & {$[0.005]$} & {$[0.004]$} & {$[0.006]$} & {$[0.004]$} & {$[0.007]$} \\
\hline \multirow{2}{*}{ cf $S M E$ ind } & -0.0336 & $-0.0836^{* * *}$ & 0.0199 & $0.0550^{*}$ & $-0.2048^{* * *}$ \\
\hline & {$[0.035]$} & {$[0.031]$} & {$[0.050]$} & {$[0.029]$} & {$[0.054]$} \\
\hline \multirow[t]{2}{*}{$\ln \left(A_{S M E \text { ind }}\right)$} & $0.0312^{* * * *}$ & $0.0414^{* * * *}$ & $0.0511^{* * * *}$ & -0.0031 & $0.0348^{* * *}$ \\
\hline & {$[0.008]$} & {$[0.005]$} & {$[0.010]$} & {$[0.006]$} & [0.009] \\
\hline \multirow[t]{2}{*}{$q_{\text {MAIN ind }}$} & $0.0127^{* *}$ & $0.0132^{* * *}$ & $0.0340^{* * *}$ & $0.0165^{* *}$ & 0.0044 \\
\hline & {$[0.005]$} & {$[0.004]$} & {$[0.008]$} & {$[0.006]$} & {$[0.005]$} \\
\hline \multirow[t]{2}{*}{$c f_{\text {MAIN ind }}$} & 0.0288 & 0.0112 & 0.0316 & -0.0396 & $0.1018^{* * *}$ \\
\hline & [0.029] & {$[0.024]$} & {$[0.030]$} & {$[0.035]$} & {$[0.044]$} \\
\hline \multirow{2}{*}{$\ln \left(A_{\text {MAIN ind }}\right)$} & $0.0226^{* * * *}$ & $0.0425^{* * *}$ & $0.0408^{* * *}$ & 0.0054 & $0.0113^{*}$ \\
\hline & {$[0.006]$} & {$[0.005]$} & {$[0.008]$} & {$[0.006]$} & {$[0.007]$} \\
\hline \# of obs & 88,492 & 90,104 & 64,392 & 60,476 & 53,728 \\
\hline$R^{2}$ & 0.151 & 0.152 & 0.175 & 0.194 & 0.191 \\
\hline \# of firms & 24,372 & 15,785 & 12,388 & 9,505 & 9,155 \\
\hline Firm FE & YES & YES & YES & YES & YES \\
\hline Year FE & YES & YES & YES & YES & YES \\
\hline
\end{tabular}


Does the SME Exchange Properly Function as a "Growth Market"?

〈Table 3〉 Panel Regressions of Private-Firm Growth on Public-Firm q - by Sub-Samples (Continued)

Panel B: Sub-samples sorted independently by private firm size and industry growth rate

\begin{tabular}{|c|c|c|c|c|c|c|}
\hline & \multicolumn{6}{|c|}{ dependent variable: annual asset growth rate of private firms } \\
\hline & \multicolumn{3}{|c|}{ small private firms } & \multicolumn{3}{|c|}{ large private firms } \\
\hline & $\begin{array}{c}\text { low growth } \\
\text { industries }\end{array}$ & $\begin{array}{l}\text { mid-growth } \\
\text { industries }\end{array}$ & $\begin{array}{l}\text { high-growth } \\
\text { industries }\end{array}$ & $\begin{array}{l}\text { low growth } \\
\text { industries }\end{array}$ & $\begin{array}{l}\text { mid-growth } \\
\text { industries }\end{array}$ & $\begin{array}{l}\text { high-growth } \\
\text { industries }\end{array}$ \\
\hline$c f_{i}$ & $\begin{array}{c}0.1932^{* * *} \\
{[0.043]}\end{array}$ & $\begin{array}{c}0.4777^{* * *} \\
{[0.032]}\end{array}$ & $\begin{array}{c}0.4413^{* * * *} \\
{[0.034]}\end{array}$ & $\begin{array}{c}0.0942^{* * *} \\
{[0.035]}\end{array}$ & $\begin{array}{c}0.3417^{* * *} \\
{[0.035]}\end{array}$ & $\begin{array}{l}0.4651^{* * *} \\
{[0.036]}\end{array}$ \\
\hline $\ln \left(A_{i}\right)$ & $\begin{array}{c}-0.6296^{* * *} \\
{[0.018]}\end{array}$ & $\begin{array}{c}-0.5197^{* * *} \\
{[0.015]}\end{array}$ & $\begin{array}{c}-0.5368^{* * *} \\
{[0.017]}\end{array}$ & $\begin{array}{l}-0.3017^{* * *} \\
{[0.009]}\end{array}$ & $\begin{array}{c}-0.2888^{* * *} \\
{[0.010]}\end{array}$ & $\begin{array}{c}-0.2832^{* * *} \\
{[0.010]}\end{array}$ \\
\hline$q_{S M E}$ ind & $\begin{array}{r}0.0109 \\
{[0.009]}\end{array}$ & $\begin{array}{l}0.0164^{* * *} \\
{[0.006]}\end{array}$ & $\begin{array}{l}0.0529^{* * *} \\
{[0.011]}\end{array}$ & $\begin{array}{r}-0.0084 \\
{[0.007]}\end{array}$ & $\begin{array}{l}0.0121^{* *} \\
{[0.005]}\end{array}$ & $\begin{array}{l}0.0333^{* * *} \\
{[0.008]}\end{array}$ \\
\hline$c f_{S M E}$ ind & $\begin{array}{r}-0.0228 \\
{[0.075]}\end{array}$ & $\begin{array}{c}0.0915^{* *} \\
{[0.046]}\end{array}$ & $\begin{array}{r}-0.1343 \\
{[0.085]}\end{array}$ & $\begin{array}{r}0.0800 \\
{[0.068]}\end{array}$ & $\begin{array}{r}0.0125 \\
{[0.039]}\end{array}$ & $\begin{array}{c}-0.2576^{* * *} \\
{[0.071]}\end{array}$ \\
\hline $\ln \left(A_{\text {SME ind }}\right)$ & $\begin{array}{c}0.0369^{* *} \\
{[0.015]}\end{array}$ & $\begin{array}{r}-0.0053 \\
{[0.010]}\end{array}$ & $\begin{array}{r}0.0035 \\
{[0.019]}\end{array}$ & $\begin{array}{l}0.0649^{* * *} \\
{[0.012]}\end{array}$ & $\begin{array}{r}-0.0047 \\
{[0.007]}\end{array}$ & $\begin{array}{l}0.0323^{* * *} \\
{[0.010]}\end{array}$ \\
\hline$q_{\text {MAIN ind }}$ & $\begin{array}{l}0.0446^{* * *} \\
{[0.011]}\end{array}$ & $\begin{array}{r}0.0149 \\
{[0.010]}\end{array}$ & $\begin{array}{r}-0.0070 \\
{[0.008]}\end{array}$ & $\begin{array}{c}0.0226^{* *} \\
{[0.010]}\end{array}$ & $\begin{array}{r}0.0087 \\
{[0.008]}\end{array}$ & $\begin{array}{c}0.0114^{*} \\
{[0.007]}\end{array}$ \\
\hline cf MAIN ind & $\begin{array}{r}-0.0300 \\
{[0.041]}\end{array}$ & $\begin{array}{r}0.0798 \\
{[0.068]}\end{array}$ & $\begin{array}{l}0.2522^{* * *} \\
{[0.069]}\end{array}$ & $\begin{array}{l}0.1038^{* * *} \\
{[0.039]}\end{array}$ & $\begin{array}{r}-0.0224 \\
{[0.040]}\end{array}$ & $\begin{array}{r}0.0179 \\
{[0.056]}\end{array}$ \\
\hline $\ln \left(A_{\text {MAIN ind }}\right)$ & $\begin{array}{l}0.0501^{* * *} \\
{[0.012]}\end{array}$ & $\begin{array}{r}0.0014 \\
{[0.009]} \\
\end{array}$ & $\begin{array}{r}-0.0134 \\
{[0.011]} \\
\end{array}$ & $\begin{array}{c}0.0213^{* * *} \\
{[0.011]}\end{array}$ & $\begin{array}{r}0.0113 \\
{[0.007]} \\
\end{array}$ & $\begin{array}{l}0.0249^{* * * *} \\
{[0.009]}\end{array}$ \\
\hline \# of obs & 30,352 & 30,130 & 28,010 & 34,040 & 30,346 & 25,718 \\
\hline$R^{2}$ & 0.155 & 0.158 & 0.156 & 0.152 & 0.172 & 0.173 \\
\hline \# of firms & 8,962 & 7,715 & 7,695 & 6,768 & 4,723 & 4,294 \\
\hline Firm FE & YES & YES & YES & YES & YES & YES \\
\hline Year FE & YES & YES & YES & YES & YES & YES \\
\hline
\end{tabular}

portunities that are particularly relevant to smaller-size firms than to larger ones, and to growing industries than to mature ones. We thus examine whether the correlation between the SME-exchanges industry $q$ and private-firms is more pronounced in those segments of the sample.

\subsubsection{Sub-Samples Sorted by Private Firm Size}

We construct two sub-samples by grouping sample private firms, each year, by the sample median of the beginning-of-year total assets of private firms. We then estimate Regression (5) of <Table $2>$ within each sub-sample.

$<$ Table 3>, the first two columns of Panel A, reports the results. While the industry $q$ of the SME exchange is highly correlated with the growth of both small and (relatively) large private firms, the magnitude of correlation is almost twice larger in the small-firm sub-sample. Specifically, the coefficient for the small-firm sub-sample is 0.0237 , whereas that of the other sub-sample is 0.0133 . In contrast, there is little dif- 
ference in the significance of the main-board industry $q$ between the small-firm and the large-firm sub-samples (0.0127 vs. 0.0132). The results thus support the notion that the SME-exchange industry q capitalizes the industry growth opportunities that are particularly relevant to small-size private firms.

As in $<$ Figure 1>, we compute economic significance of each coefficient by the fraction of the mean private-firm growth that is associated with the coefficient multiplied by its own standard deviation. Panel A of $<$ Figure $2>$ shows that, for the growth of small private firms, the economic significance of the SME-exchange industry $q$ is nearly twice as large as that of the main-board industry q $(10.0 \%$ vs. $5.3 \%)$. Even for the growth of large private firms, the SME-exchange industry $q$ is more important than the main-board industry $q$. However, the difference is rather small (8.5\% vs. $7.8 \%)$. Put differently, the results indicate that the SME-exchange industry $\mathrm{q}$ is more highly correlated with the growth of small private firms than with the growth of large private firms, whereas the main-board industry q shows the exactly opposite pattern.

\section{〈Figure 2〉 Economic Significance of Estimated Coefficients on Industry q Ratio - by Sub-Samples}

This figure shows the economic significance of the coefficients on the SME-exchange industry q ratio and the main-board industry q ratio, estimated within sub-samples. Specifically, the coefficients are from Panel A of <Table 3>. The economic significance is compute as the fraction of the mean dependent variable that is associated with the estimated coefficient times its own standard deviation. The statistics used in the computation are from the corresponding sub-sample.

Panel A: Economic significance by subsamples sorted by private-firm size

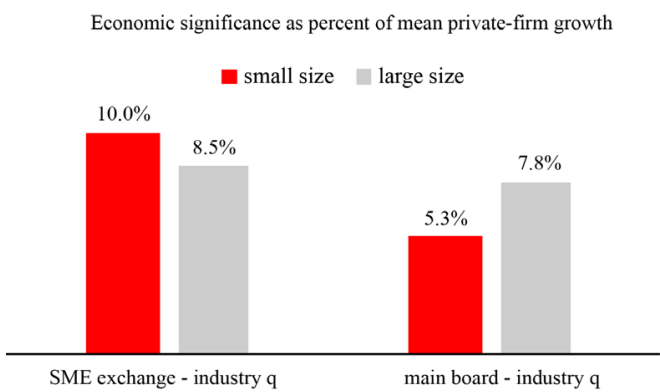

Panel B: Economic significance by subsamples sorted by industry growth rate

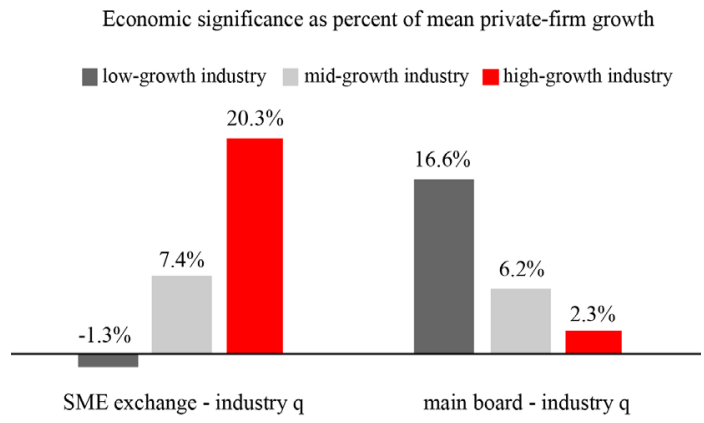

\subsubsection{Sub-Samples Sorted by Industry Growth Rate}

Another set of sub-samples is constructed by the average growth rate at the industry level. Specifically, for each industry, we compute the aggregate growth rate (aver- 
aged over time) and assign the sample industries into three groups. We then estimate Regression (5) of <Table $2>$ within each sub-sample.

The results are in the third to fifth columns of $<$ Table $3>$, Panel A. It is unmistakable that the SME-exchange industry $q$ is more highly correlated with the growth of private firms, the faster do their industries grow. The coefficients on the SMEexchange industry q increases from -0.002 to 0.016 to 0.048 from the low-growth to the high-growth sub-samples. In contrast, the coefficient on the main-board industry q decreases from 0.034 to 0.017 to 0.004 .

$<$ Figure 2>, Panel B, visualizes the economic significance of those coefficients. A one standard deviation change in the SME-exchange industry q alone explains more than $20 \%$ of the typical annual growth of private firms. ${ }^{9)}$ In contrast, the industry q of the main board shows the opposite pattern. It has the greatest coefficient in the lowest-growth sub-sample, with which the economic significance is computed as $16.6 \%$ of the mean growth of private firms. ${ }^{10}$ ) In the highest-growth sub-sample, the main board q ratio is small in magnitude (0.004) and statistically insignificant.

\subsubsection{Sub-Samples Sorted Independently by Private Firm Size and Industry Growth Rate}

We now sort our sample by private-firm size and industry growth rate. This independent double sorting yields as many as six sub-samples and we estimate Regression (5) of $<$ Table $2>$ within each of them.

The results are reported in Panel B of <Table 3>. We find that the significance of the industry q of the SME exchange is affected both by the size of private firm and by the growth profile of industry. More specifically, conditional on high industry growth, the coefficient on the industry q of the SME exchange is larger in magnitude in the small-firm sub-sample than in the large-firm sub-sample (0.0529 vs. 0.0333). Conversely, within small firms, the high-growth sub-sample has a larger coefficient than the low-growth sub-sample (0.0529 vs. 0.0109). Even within large firms, industry growth is important, as the coefficient differs between the high-growth and the lowgrowth industries (0.0333 vs. -0.0084). As in the preceding analyses, the industry q of the main board shows the opposite pattern. It enters the regression with a significant and positive coefficient only in the low-growth sub-sample, regardless of the size of private firms.

9) The standard deviation of the SME exchange $q$ is 0.461 in the high-growth sub-sample. When multiplied by the estimated coefficient, this variation in q implies a change in the dependent variable of $2.2 \%$. In this sub-sample, the average annual growth of private firms is $10.9 \%$.

10) In this sub-sample, the standard deviation of the main-board industry $q$ is 0.307 and the mean private-firm growth is $6.3 \%$. Thus, the estimated coefficient of 0.034 is equivalent to $16.6 \%$ of the mean growth of private firms (i.e., $0.034 \times 0.307 / 0.063$ ). 
In sum, while both firm size and industry growth are important, it seems to be the growth profile of industry that determines which of the two exchanges' industry q ratios better represents the industry growth opportunities relevant to private firms. For growing industries, it is the SME-exchange q. For mature industries, it is the main-board q.

\section{Correlation by Funding Sources of Private-Firm Growth}

We now decompose the asset growth of private SMEs by funding sources. Broadly speaking, asset changes are funded either internally (i.e., retained earnings) or externally (i.e., newly contributed capital). External funding is then further divided into liabilities and equities, the former of which includes both debt and non-debt liabilities such as trade credits. By associating the SME growth funded by different sources with the SME exchange stock prices, we examine which type of financing options are best reflected in the SME exchange stock prices.

\subsection{Full-Sample Estimation}

We consider the following base-line equation:

$$
\Delta F_{i, t}=c f_{i, t-1}+\ln \left(A_{i, t-1}\right)+q_{\text {peer }, t-1}+c f_{\text {peer }, t-1}+\ln \left(A_{\text {peer }, t-1}\right)+f_{i}+y_{t}+\varepsilon_{i, t},
$$

where $\Delta F_{i, t}$ is private firm $i$ 's change in a certain balance-sheet item (detailed below) during year $t$, scaled by the total assets at the end of year $t-1$. Similar to Chen and Chen (2012), we consider the annual changes in: financial liabilities (i.e., debt capital), non-financial liabilities, and equity capital.11) All other variables are the same as those in Eq. (1) and we estimate a modified version of Regressions (5) and (6) of <Table $2>$ in which the dependent variable is $\Delta F$, not $\Delta A$.

$<$ Table $4>$ reports the results. The first column shows that when the source of funding is debt, the main-board industry q has a slightly larger coefficient than the SMEexchange industry q (0.0035 vs. 0.0036). Given the standard deviations of the two q's (0.441 for the SME exchange $q$ and 0.422 for the main board $q$ ), however, their economic significance should be deemed similar. The next column shows that when the year fixed effects are replaced by the market q's of the two exchanges, the main-board market $q$ and the SME-exchange industry $q$ are significantly positive. It thus means that the finding in Regression (6) of <Table 2>-namely, the SME exchange prices contain industry-specific information while the main-board prices embody marketwide one-is related to the debt-funded growth of private firms.

11) Other funding sources include changes in cumulative retained earnings and changes in treasury stocks, which are not of our interest in this paper. 
Does the SME Exchange Properly Function as a "Growth Market"?

For the other two funding sources (reported in the remaining columns), the coefficient on the SME-exchange industry $q$ is always greater than that on the main-board industry q. Beginning with non-debt liabilities, the results show that this funding source is highly industry-specific, as is also noted by earlier studies (e.g., Chan et al., 2006). Specifically, neither of the two market q ratios enters the regression significantly, while both exchanges' industry q ratios are highly significant. Still, the magnitude is larger for the SME-exchange industry q than the main-board industry q.

\section{〈Table 4〉Panel Regressions of Private-Firm Growth on Public-Firm q - by Funding Sources}

The table reports firm-year panel regressions of the annual total-asset growth rate of private firms on the average q ratios of public firms and other control variables. The asset growth rate is computed separated for its funding sources-i.e., changes in debt capital, changes in non-debt liabilities, and changes in equity capital, scaled by lagged total assets. The regressors are the same as those in $\langle$ Table 2$\rangle$ and $\langle$ Table 3$\rangle$. Numbers in brackets are the cluster-robust standard errors. ${ }^{*},{ }^{* *}$, and ${ }^{* * *}$ indicate the statistical significance at the $10 \%, 5 \%$ and $1 \%$ levels, respectively.

\begin{tabular}{|c|c|c|c|c|c|c|}
\hline \multirow{3}{*}{$\overline{c f_{i}}$} & \multicolumn{6}{|c|}{ dependent variable: } \\
\hline & \multicolumn{2}{|c|}{$\triangle D e b t$} & \multicolumn{2}{|c|}{$\triangle N o n-d e b t$ liabilities } & \multicolumn{2}{|c|}{$\triangle$ Equity } \\
\hline & $\begin{array}{l}0.1395^{* * *} \\
{[0.009]}\end{array}$ & $\begin{array}{l}0.1429^{* * *} \\
{[0.009]}\end{array}$ & $\begin{array}{c}-0.0681^{* * *} \\
{[0.008]}\end{array}$ & $\begin{array}{c}{ }_{-0.0701^{* * *}} \\
{[0.008]}\end{array}$ & $\begin{array}{l}-0.0225^{* * *} \\
{[0.003]}\end{array}$ & $\begin{array}{c}-0.0247^{* * *} \\
{[0.003]}\end{array}$ \\
\hline $\ln \left(A_{i}\right)$ & $\begin{array}{c}-0.1232^{* * *} \\
{[0.002]}\end{array}$ & $\begin{array}{c}-0.1270^{* * *} \\
{[0.002]}\end{array}$ & $\begin{array}{c}-0.0953^{* * *} \\
{[0.002]}\end{array}$ & $\begin{array}{c}-0.0947^{* * *} \\
{[0.002]}\end{array}$ & $\begin{array}{c}-0.0222^{* * *} \\
{[0.001]}\end{array}$ & $\begin{array}{c}-0.0211^{* * *} \\
{[0.001]}\end{array}$ \\
\hline$q_{S M E}$ ind & $\begin{array}{c}0.0035^{* *} \\
{[0.002]}\end{array}$ & $\begin{array}{l}0.0048^{* * *} \\
{[0.002]}\end{array}$ & $\begin{array}{l}0.0057^{* * *} \\
{[0.001]}\end{array}$ & $\begin{array}{l}0.0058^{* * *} \\
{[0.001]}\end{array}$ & $\begin{array}{l}0.0062^{* * *} \\
{[0.001]}\end{array}$ & $\begin{array}{l}0.0069^{* * *} \\
{[0.001]}\end{array}$ \\
\hline$c f_{S M E \text { ind }}$ & $\begin{array}{r}-0.0155 \\
{[0.014]}\end{array}$ & $\begin{array}{c}-0.0303^{* *} \\
{[0.014]}\end{array}$ & $\begin{array}{c}-0.04366^{* * *} \\
{[0.011]}\end{array}$ & $\begin{array}{c}-0.0439^{* * * *} \\
{[0.011]}\end{array}$ & $\begin{array}{c}-0.0226^{* * *} \\
{[0.005]}\end{array}$ & $\begin{array}{c}-0.0268^{* * *} \\
{[0.005]}\end{array}$ \\
\hline $\ln \left(A_{S M E}\right.$ ind $)$ & $\begin{array}{l}0.0198^{* * *} \\
{[0.002]}\end{array}$ & $\begin{array}{l}0.0151^{* * *} \\
{[0.002]}\end{array}$ & $\begin{array}{l}0.0083^{* * *} \\
{[0.002]}\end{array}$ & $\begin{array}{l}0.0110^{* * *} \\
{[0.002]}\end{array}$ & $\begin{array}{l}0.0027^{* * *} \\
{[0.001]}\end{array}$ & $\begin{array}{l}0.0061^{* * *} \\
{[0.001]}\end{array}$ \\
\hline$q_{S M E ~ m k t}$ & & $\begin{array}{c}-0.0429^{* * *} \\
{[0.004]}\end{array}$ & & $\begin{array}{c}-0.0063^{*} \\
{[0.003]}\end{array}$ & & $\begin{array}{l}0.0255^{* * *} \\
{[0.002]}\end{array}$ \\
\hline$q_{\text {MAIN ind }}$ & $\begin{array}{c}0.0036^{*} \\
{[0.002]}\end{array}$ & $\begin{array}{r}0.0024 \\
{[0.002]}\end{array}$ & $\begin{array}{l}0.0053^{* * *} \\
{[0.002]}\end{array}$ & $\begin{array}{l}0.0052^{* * *} \\
{[0.002]}\end{array}$ & $\begin{array}{l}0.0022^{* *} \\
{[0.001]}\end{array}$ & $\begin{array}{l}0.0026^{* * *} \\
{[0.001]}\end{array}$ \\
\hline$c f_{\text {MAIN ind }}$ & $\begin{array}{r}0.0066 \\
{[0.012]}\end{array}$ & $\begin{array}{l}0.0355^{* * *} \\
{[0.012]}\end{array}$ & $\begin{array}{c}-0.0218^{* *} \\
{[0.009]}\end{array}$ & $\begin{array}{c}-0.0160^{*} \\
{[0.009]}\end{array}$ & $\begin{array}{r}-0.0045 \\
{[0.004]}\end{array}$ & $\begin{array}{l}-0.0141^{* * *} \\
{[0.003]}\end{array}$ \\
\hline $\ln \left(A_{\text {MAIN ind }}\right)$ & $\begin{array}{l}0.0177^{* * *} \\
{[0.002]}\end{array}$ & $\begin{array}{l}0.0151^{* * *} \\
{[0.002]}\end{array}$ & $\begin{array}{l}0.0134^{* * *} \\
{[0.002]}\end{array}$ & $\begin{array}{l}0.0157^{* * *} \\
{[0.002]}\end{array}$ & $\begin{array}{r}0.0010 \\
{[0.001]}\end{array}$ & $\begin{array}{l}0.0034^{* * *} \\
{[0.001]}\end{array}$ \\
\hline$q_{\text {MAIN mkt }}$ & & $\begin{array}{l}0.1679^{* * *} \\
{[0.009]}\end{array}$ & & $\begin{array}{r}0.0056 \\
{[0.007]}\end{array}$ & & $\begin{array}{l}-0.0447^{* * * *} \\
{[0.004]}\end{array}$ \\
\hline \# of obs & 178,596 & 178,596 & 178,596 & 178,596 & 178,596 & 178,596 \\
\hline$R^{2}$ & 0.071 & 0.067 & 0.056 & 0.053 & 0.030 & 0.026 \\
\hline \# of firms & 31,048 & 31,048 & 31,048 & 31,048 & 31,048 & 31,048 \\
\hline Firm FE & YES & YES & YES & YES & YES & YES \\
\hline Year FE & YES & $\mathrm{NO}$ & YES & $\mathrm{NO}$ & YES & NO \\
\hline
\end{tabular}


The last two columns of $<$ Table $4>$ show that the SME-exchange industry $q$ is most highly correlated with the equity-financed growth of private firms. It is so in comparison with the private-firm growth funded by other sources (reported in the preceding four columns), and is also the case when compared with the main-board industry $q$ in the same regression. This pattern is robust to replacing the year fixed effects by the market q's. In this alternative specification with market q's, it is notable that the SME-exchange market $q$, not the main-board market $q$, enters the regression with a significant and positive coefficient. Nevertheless, the SME exchange's industryspecific $\mathrm{q}$ is the most significant economically, confirming that the SME exchange capitalizes industry-specific growth opportunities.

$<$ Figure $3>$ summarizes the results in $<$ Table $4>$ by plotting the economic significance of the coefficients in columns one, three, and five. Without a doubt, it is the SME-exchange industry $q$ that best represents industry opportunities relevant to private-firm growth. It is particularly so when the growth is funded by equity.

\section{〈Figure 3〉 Economic Significance of Estimated Coefficients on Industry a Ratio - by Funding Sources}

This figure shows the economic significance of the coefficients on the SME-exchange industry q ratio and the main-board industry q ratio, estimated for each funding source. Specifically, the coefficients are from $\langle$ Table 4$\rangle$ and the economic significance is compute as the fraction of the mean dependent variable that is associated with the estimated coefficient times its own standard deviation.

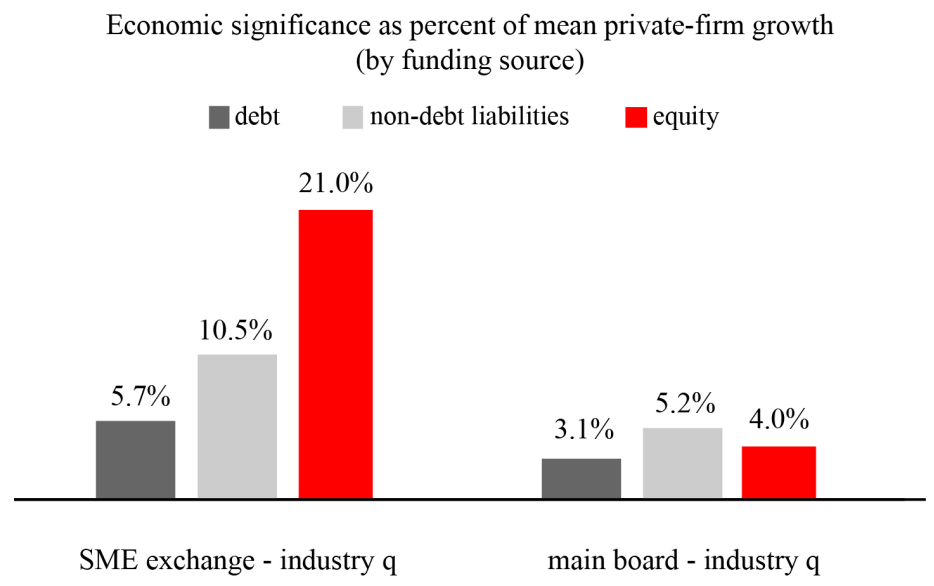

\subsection{Sub-Sample Analysis}

As in the asset-growth analysis, we use two sets of sub-samples-one by the size of private firms and the other by industry growth. We begin with firm size and report the results in Panel A of $<$ Table 5>. It is shown that the industry q of the SME ex- 
Does the SME Exchange Properly Function as a "Growth Market"?

change is relevant to the equity-financed growth of private firms especially when the private firms are small in size. For other types of funding (i.e., liabilities), we observe little difference between the small-size and the large sub-samples. In contrast, it is exactly with this liability funding where the main-board industry a shows a differing pattern between the size-sorted sub-samples. Specifically, the main-board $q$ is correlated more with the liability-funded growth of large private firms than with the liability-funded growth of small private firms.

\section{〈Table 5〉Panel Regressions of Private-Firm Growth on Public-Firm q - by Funding Source and Sub-Samples}

The table reports firm-year panel regressions of the annual total-asset growth rate of private firms on the average q ratios of public firms and other control variables. The asset growth rate is computed separated for its funding sources-i.e., changes in debt capital, changes in nondebt liabilities, and changes in equity capital, scaled by lagged total assets. Regressions are estimated within sub-samples sorted by private-firm size (Panel A), by industry growth rate (Panel B), or by both (Panel C). The regressors are the same as those in $\langle$ Table 2$\rangle$, $\langle$ Table 3$\rangle$, and $\langle$ Table 4$\rangle$. Numbers in brackets are the cluster-robust standard errors. ${ }^{*},{ }^{* *}$, and ${ }^{* * *}$ indicate the statistical significance at the $10 \%, 5 \%$ and $1 \%$ levels, respectively.

Panel A: Sub-samples sorted by private firm size

\begin{tabular}{|c|c|c|c|c|c|c|}
\hline & \multicolumn{6}{|c|}{ dependent variable: } \\
\hline & \multicolumn{2}{|c|}{$\Delta D e b t$} & \multicolumn{2}{|c|}{$\triangle$ Non-debt liabilities } & \multicolumn{2}{|c|}{$\triangle$ Equity } \\
\hline & \multicolumn{2}{|c|}{$\overline{\text { sort by private firm size }}$} & \multicolumn{2}{|c|}{$\overline{\text { sort by private firm size }}$} & \multicolumn{2}{|c|}{ sort by private firm size } \\
\hline & small & large & small & large & small & large \\
\hline \multirow[t]{2}{*}{$\overline{c f_{i}}$} & $0.1961^{* * *}$ & $0.1112^{* * *}$ & $-0.0303^{* * * *}$ & $-0.0817^{* * * *}$ & -0.0089 & $-0.0279^{* * * *}$ \\
\hline & {$[0.014]$} & {$[0.013]$} & {$[0.011]$} & {$[0.012]$} & {$[0.005]$} & {$[0.005]$} \\
\hline \multirow[t]{2}{*}{$\ln \left(A_{i}\right)$} & $-0.1783^{* * *}$ & $-0.1094^{* * *}$ & $-0.1687^{* * *}$ & $-0.0826^{* * *}$ & $-0.0371^{* * *}$ & $-0.0189^{* * *}$ \\
\hline & {$[0.006]$} & {$[0.003]$} & {$[0.005]$} & {$[0.003]$} & {$[0.002]$} & {$[0.001]$} \\
\hline \multirow[t]{2}{*}{$q_{S M E}$ ind } & 0.0028 & 0.0018 & $0.0043^{*}$ & $0.0051^{* * *}$ & $0.0099^{* * *}$ & $0.0024^{* * *}$ \\
\hline & {$[0.003]$} & {$[0.002]$} & [0.002] & {$[0.002]$} & {$[0.001]$} & {$[0.001]$} \\
\hline \multirow[t]{2}{*}{$c f_{\text {SME ind }}$} & $-0.0537^{* *}$ & 0.0200 & -0.0174 & $-0.0519^{* * * *}$ & -0.0031 & $-0.0378^{* * *}$ \\
\hline & {$[0.022]$} & [0.019] & {$[0.018]$} & {$[0.016]$} & {$[0.008]$} & {$[0.008]$} \\
\hline \multirow[t]{2}{*}{$\ln \left(A_{\text {SME ind }}\right)$} & $0.0104^{* *}$ & $0.0221^{* * *}$ & $0.0080^{* *}$ & $0.0043^{*}$ & 0.0023 & $0.0019^{*}$ \\
\hline & [0.004] & [0.003] & [0.003] & [0.002] & [0.002] & [0.001] \\
\hline \multirow[t]{2}{*}{$q_{M A I N \text { ind }}$} & 0.0014 & $0.0055^{*}$ & 0.0020 & $0.0070^{* * * *}$ & 0.0023 & 0.0006 \\
\hline & [0.003] & [0.003] & [0.003] & [0.002] & [0.002] & {$[0.001]$} \\
\hline \multirow[t]{2}{*}{$c f_{\text {MAIN ind }}$} & 0.0229 & 0.0147 & -0.0012 & $-0.0299^{* *}$ & -0.0044 & -0.0016 \\
\hline & [0.019] & [0.015] & [0.014] & [0.013] & [0.006] & [0.005] \\
\hline \multirow[t]{2}{*}{$\operatorname{In}\left(A_{\text {MAIN ind }}\right)$} & $0.0059^{*}$ & $0.0213^{* * *}$ & $0.0115^{* * *}$ & $0.0166^{* * * *}$ & 0.0011 & 0.0002 \\
\hline & [0.003] & [0.003] & [0.003] & [0.002] & [0.001] & [0.001] \\
\hline \# of obs & 88,492 & 90,104 & 88,492 & 90,104 & 88,492 & 90,104 \\
\hline$R^{2}$ & 0.049 & 0.062 & 0.050 & 0.042 & 0.028 & 0.020 \\
\hline \# of firms & 24,372 & 15,785 & 24,372 & 15,785 & 24,372 & 15,785 \\
\hline Firm FE & YES & YES & YES & YES & YES & YES \\
\hline Year FE & YES & YES & YES & YES & YES & YES \\
\hline
\end{tabular}


〈Table 5〉 Panel Regressions of Private-Firm Growth on Public-Firm q - by Funding Source and Sub-Samples (Continued)

Panel B: Sub-samples sorted by industry growth rate

\begin{tabular}{|c|c|c|c|c|c|c|c|c|c|}
\hline & \multicolumn{9}{|c|}{ dependent variable: } \\
\hline & \multicolumn{3}{|c|}{$\triangle D e b t$} & \multicolumn{3}{|c|}{$\triangle$ Non-debt liabilities } & \multicolumn{3}{|c|}{$\triangle$ Equity } \\
\hline & \multicolumn{3}{|c|}{ sort by industry growth rate } & \multicolumn{3}{|c|}{ sort by industry growth rate } & \multicolumn{3}{|c|}{ sort by industry growth rate } \\
\hline & low & mid & high & low & mid & high & low & mid & high \\
\hline$\overline{c f_{i}}$ & $\begin{array}{l}0.1121^{* * *} \\
{[0.017]}\end{array}$ & $\begin{array}{l}0.1728^{* * *} \\
{[0.015]}\end{array}$ & $\begin{array}{l}0.1532^{* * *} \\
{[0.016]}\end{array}$ & $\begin{array}{c}-0.1372^{* * *} \\
{[0.015]}\end{array}$ & $\begin{array}{c}-0.0255^{* *} \\
{[0.012]}\end{array}$ & $\begin{array}{c}-0.0194^{*} \\
{[0.012]}\end{array}$ & $\begin{array}{c}-0.0203^{* * *} \\
{[0.005]}\end{array}$ & $\begin{array}{c}-0.0342^{* * *} \\
{[0.006]}\end{array}$ & $\begin{array}{c}-0.0138^{*} \\
{[0.007]}\end{array}$ \\
\hline $\ln \left(A_{i}\right)$ & $\begin{array}{c}-0.1604^{* * *} \\
{[0.004]}\end{array}$ & $\begin{array}{c}-0.1022^{* * * *} \\
{[0.004]}\end{array}$ & $\begin{array}{l}-0.0935^{* * *} \\
{[0.004]}\end{array}$ & $\begin{array}{c}-0.0856^{* * *} \\
{[0.003]}\end{array}$ & $\begin{array}{c}-0.0995^{* * *} \\
{[0.003]}\end{array}$ & $\begin{array}{l}-0.1137^{* * * *} \\
{[0.003]}\end{array}$ & $\begin{array}{c}-0.0160^{* * * *} \\
{[0.001]}\end{array}$ & $\begin{array}{c}-0.0267^{* * *} \\
{[0.002]}\end{array}$ & $\begin{array}{c}-0.0278^{* * * *} \\
{[0.002]}\end{array}$ \\
\hline$q_{S M E}$ ind & $\begin{array}{c}-0.0075^{* *} \\
{[0.003]}\end{array}$ & $\begin{array}{r}0.0020 \\
{[0.002]}\end{array}$ & $\begin{array}{l}0.0135^{* * *} \\
{[0.003]}\end{array}$ & $\begin{array}{r}-0.0013 \\
{[0.003]}\end{array}$ & $\begin{array}{l}0.0078^{* * *} \\
{[0.002]}\end{array}$ & $\begin{array}{l}0.0088^{* * * *} \\
{[0.003]}\end{array}$ & $\begin{array}{l}0.0043^{* * *} \\
{[0.001]}\end{array}$ & $\begin{array}{l}0.0044^{* * *} \\
{[0.001]}\end{array}$ & $\begin{array}{l}0.0124^{* * *} \\
{[0.002]}\end{array}$ \\
\hline$c f_{S M E}$ ind & $\begin{array}{r}0.0018 \\
{[0.031]}\end{array}$ & $\begin{array}{c}0.0390^{* *} \\
{[0.018]}\end{array}$ & $\begin{array}{r}-0.0382 \\
{[0.032]}\end{array}$ & $\begin{array}{r}-0.0299 \\
{[0.023]}\end{array}$ & $\begin{array}{r}0.0138 \\
{[0.015]}\end{array}$ & $\begin{array}{c}-0.0827^{* * *} \\
{[0.027]}\end{array}$ & $\begin{array}{c}-0.0346^{* * *} \\
{[0.011]}\end{array}$ & $\begin{array}{r}-0.0054 \\
{[0.007]}\end{array}$ & $\begin{array}{c}-0.0429^{* * *} \\
{[0.013]}\end{array}$ \\
\hline $\ln \left(A_{\text {SME ind }}\right)$ & $\begin{array}{l}0.0291^{* * *} \\
{[0.005]}\end{array}$ & $\begin{array}{c}-0.0063^{* *} \\
{[0.003]}\end{array}$ & $\begin{array}{l}0.0170^{* * *} \\
{[0.005]}\end{array}$ & $\begin{array}{r}0.0038 \\
{[0.004]}\end{array}$ & $\begin{array}{r}-0.0020 \\
{[0.003]}\end{array}$ & $\begin{array}{c}0.0086^{* *} \\
{[0.004]}\end{array}$ & $\begin{array}{c}0.0034^{*} \\
{[0.002]}\end{array}$ & $\begin{array}{r}-0.0003 \\
{[0.001]}\end{array}$ & $\begin{array}{c}0.0037^{*} \\
{[0.002]}\end{array}$ \\
\hline$q_{\text {MAIN ind }}$ & $\begin{array}{c}0.0083^{*} \\
{[0.005]}\end{array}$ & $\begin{array}{r}0.0045 \\
{[0.004]}\end{array}$ & $\begin{array}{r}0.0019 \\
{[0.003]}\end{array}$ & $\begin{array}{l}0.0100^{* * * *} \\
{[0.004]}\end{array}$ & $\begin{array}{r}0.0051 \\
{[0.003]}\end{array}$ & $\begin{array}{r}0.0016 \\
{[0.002]}\end{array}$ & $\begin{array}{l}0.0069^{* * *} \\
{[0.002]}\end{array}$ & $\begin{array}{c}0.0024^{*} \\
{[0.001]}\end{array}$ & $\begin{array}{r}0.0001 \\
{[0.002]}\end{array}$ \\
\hline$c f_{\text {MAIN ind }}$ & $\begin{array}{r}0.0263 \\
{[0.019]}\end{array}$ & $\begin{array}{r}0.0032 \\
{[0.022]}\end{array}$ & $\begin{array}{c}0.0447^{*} \\
{[0.025]}\end{array}$ & $\begin{array}{r}-0.0039 \\
{[0.015]}\end{array}$ & $\begin{array}{c}-0.0417^{* *} \\
{[0.018]}\end{array}$ & $\begin{array}{r}0.0039 \\
{[0.020]}\end{array}$ & $\begin{array}{r}-0.0062 \\
{[0.005]}\end{array}$ & $\begin{array}{r}-0.0069 \\
{[0.009]}\end{array}$ & $\begin{array}{l}0.0216^{* *} \\
{[0.011]}\end{array}$ \\
\hline $\ln \left(A_{\text {MAIN ind }}\right)$ & $\begin{array}{l}0.0249^{* * * *} \\
{[0.005]}\end{array}$ & $\begin{array}{r}0.0033 \\
{[0.003]}\end{array}$ & $\begin{array}{r}-0.0041 \\
{[0.004]}\end{array}$ & $\begin{array}{c}0.0075^{* *} \\
{[0.003]}\end{array}$ & $\begin{array}{c}0.0064^{* *} \\
{[0.003]}\end{array}$ & $\begin{array}{l}0.0123^{* * * *} \\
{[0.003]}\end{array}$ & $\begin{array}{l}0.0039^{* * *} \\
{[0.001]}\end{array}$ & $\begin{array}{c}-0.0022^{*} \\
{[0.001]}\end{array}$ & $\begin{array}{r}-0.0006 \\
{[0.002]}\end{array}$ \\
\hline \# of obs & 64,392 & 60,476 & 53,728 & 64,392 & 60,476 & 53,728 & 64,392 & 60,476 & 53,728 \\
\hline$R^{2}$ & 0.094 & 0.065 & 0.054 & 0.048 & 0.065 & 0.075 & 0.025 & 0.031 & 0.040 \\
\hline \# of firms & 12,388 & 9,505 & 9,155 & 12,388 & 9,505 & 9,155 & 12,388 & 9,505 & 9,155 \\
\hline Firm FE & YES & YES & YES & YES & YES & YES & YES & YES & YES \\
\hline Year FE & YES & YES & YES & YES & YES & YES & YES & YES & YES \\
\hline
\end{tabular}


Does the SME Exchange Properly Function as a "Growth Market"

〈Table 5> Panel Regressions of Private-Firm Growth on Public-Firm q - by Funding Source and Sub-Samples (Continued)

Panel C: Sub-samples sorted independently by private firm size and industry growth rate

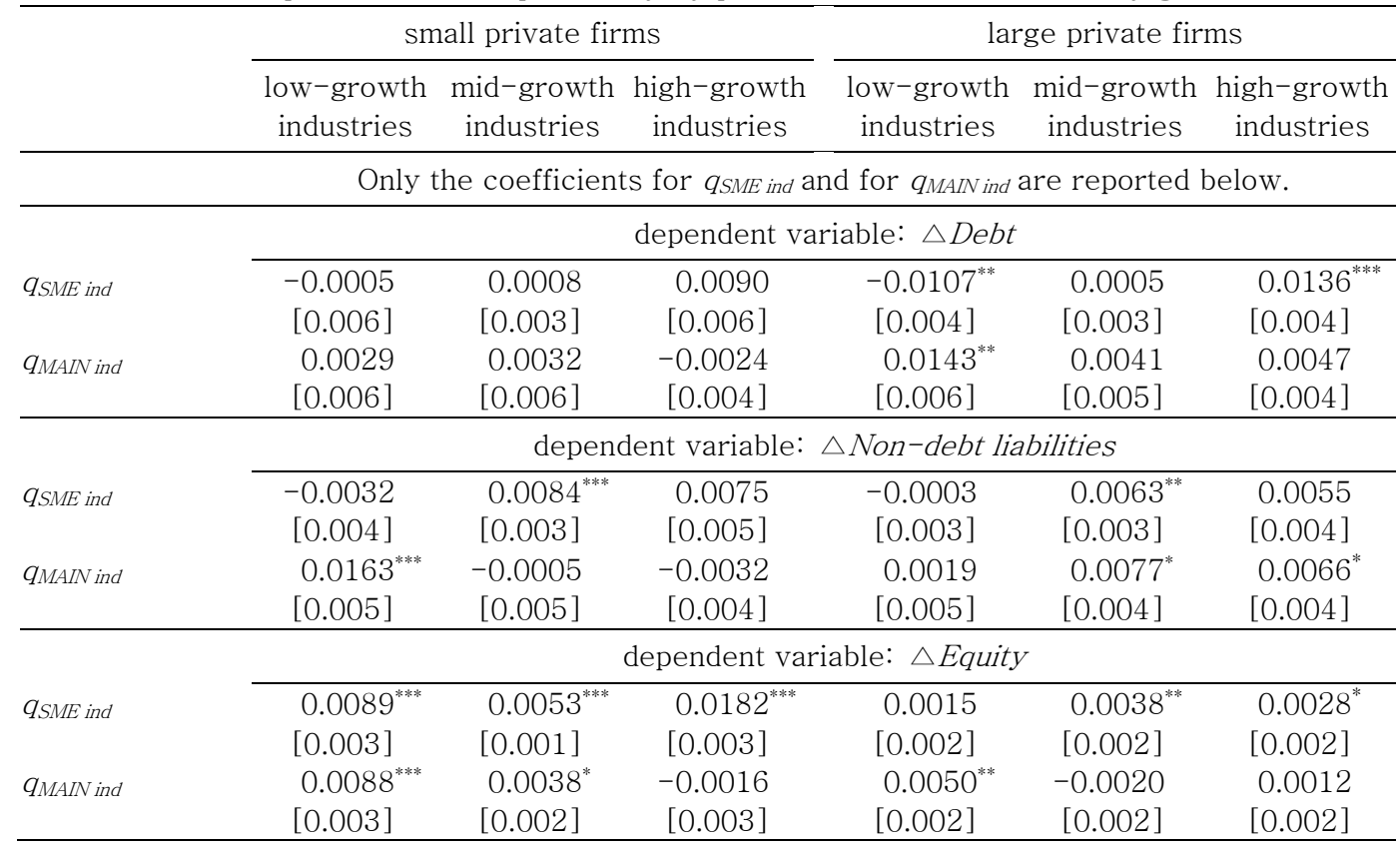

Moving on to the sub-samples sorted by industry growth rate, Panel B of <Table 5> shows that the SME-exchange industry $q$ is significantly correlated with the growth of private firms, funded by any of the three sources, as long as the private firm belongs to a growing industry. In other words, the effect of industry growth is prevalent across all three types of funding and the coefficient on the SME-exchange industry $q$ increases from low-growth to high-growth industries both economically and statistically. The industry-growth effect is also present in the correlation between the mainboard industry $q$ and private-firm growth. However, the effect is at work in the reverse fashion. For each of the three funding sources, the correlation decreases from low-growth to high-growth industries.

Finally, we examine the sub-samples sorted independently by private-firm size and industry growth. To save space, we only tabulate the coefficients on the industry $q$ ratios of the two exchanges. Panel $\mathrm{C}$ of $<$ Table $5>$ shows that the SME-exchange industry $q$ is most highly correlated with the equity-funded growth of small private firms in growing industries. On the other hand, the main-board industry $q$ is most significant when the growth of private firms is funded by liabilities-i.e., debt or nondebt liabilities-and the private firm is from a low-growth industry. 


\section{Robustness Checks}

\subsection{Correlation between SME Exchange Prices and Lead Growth of Pri- vate Firms}

We now gauge the extent to which the contemporaneous correlation between the SME exchange stock prices and private-firm growth is driven by noise and is thus reversed subsequently. To that end, we repeat the analysis by leading the privatefirm growth and see whether the leading growth of private firms is negatively correlated with the SME exchange stock prices.

$<$ Table 6> shows the results when the growth of private firms is leading by one year. The main finding here is that there is no evidence of reversal. More specifically,

\section{〈Table 6> Panel Regressions of Leading Private-Firm Growth on Public-Firm a}

The table reports firm-year panel regressions of the annual total-asset growth rate of private firms, which is leading by one year, on the average q ratios of public firms and other control variables. Regressions are estimated for the full sample as well as within subsamples sorted by private-firm size or by industry growth rate. The regressors are the same as those in 〈Table 2〉. Numbers in brackets are the cluster-robust standard errors. *, ${ }^{* *}$, and ${ }^{* * *}$ indicate the statistical significance at the $10 \%, 5 \%$ and $1 \%$ levels, respectively.

\begin{tabular}{|c|c|c|c|c|c|c|}
\hline & \multicolumn{6}{|c|}{ dependent variable: $\triangle \mathrm{A}$, leading by 1 year } \\
\hline & \multirow{2}{*}{ full sample } & \multicolumn{2}{|c|}{ private firm size } & \multicolumn{3}{|c|}{ industry growth rate } \\
\hline & & small & large & low & mid & high \\
\hline$c f_{i}$ & $\begin{array}{l}0.1269^{* * *} \\
{[0.013]}\end{array}$ & $\begin{array}{l}0.1139^{* * *} \\
{[0.021]}\end{array}$ & $\begin{array}{l}0.1015^{\text {*** }} \\
{[0.018]}\end{array}$ & $\begin{array}{l}0.0649^{* * * *} \\
{[0.024]}\end{array}$ & $\begin{array}{c}0.1437^{* * *} \\
{[0.020]}\end{array}$ & $\begin{array}{l}0.1831^{* * *} \\
{[0.022]}\end{array}$ \\
\hline $\ln \left(A_{j}\right)$ & $\begin{array}{c}-0.2038^{* * *} \\
{[0.003]}\end{array}$ & $\begin{array}{l}-0.1671^{* * *} \\
{[0.008]}\end{array}$ & $\begin{array}{l}-0.2127^{* * *} \\
{[0.005]}\end{array}$ & $\begin{array}{c}-0.2039^{* * *} \\
{[0.006]}\end{array}$ & $\begin{array}{c}-0.2085^{* * *} \\
{[0.005]}\end{array}$ & $\begin{array}{l}-0.2130^{* * *} \\
{[0.006]}\end{array}$ \\
\hline$q_{S M E \text { ind }}$ & $\begin{array}{r}-0.0018 \\
{[0.003]}\end{array}$ & $\begin{array}{r}0.0067 \\
{[0.004]}\end{array}$ & $\begin{array}{c}-0.0082^{* *} \\
{[0.003]}\end{array}$ & $\begin{array}{c}-0.0158^{* * *} \\
{[0.005]}\end{array}$ & $\begin{array}{r}0.0027 \\
{[0.004]}\end{array}$ & $\begin{array}{r}0.0077 \\
{[0.005]}\end{array}$ \\
\hline$c f_{\text {SME ind }}$ & $\begin{array}{c}-0.0461^{* *} \\
{[0.020]}\end{array}$ & $\begin{array}{c}-0.0778^{* *} \\
{[0.031]}\end{array}$ & $\begin{array}{r}-0.0242 \\
{[0.028]}\end{array}$ & $\begin{array}{l}0.1295^{* * *} \\
{[0.041]}\end{array}$ & $\begin{array}{r}-0.0302 \\
{[0.027]}\end{array}$ & $\begin{array}{c}-0.1469^{* * *} \\
{[0.049]}\end{array}$ \\
\hline $\ln \left(A_{S M E}\right.$ ind $)$ & $\begin{array}{l}0.0107^{* * *} \\
{[0.003]}\end{array}$ & $\begin{array}{r}-0.0090 \\
{[0.006]}\end{array}$ & $\begin{array}{l}0.0203^{* * *} \\
{[0.004]}\end{array}$ & $\begin{array}{r}0.0045 \\
{[0.007]}\end{array}$ & $\begin{array}{c}-0.0110^{* *} \\
{[0.004]}\end{array}$ & $\begin{array}{r}0.0086 \\
{[0.007]}\end{array}$ \\
\hline$q_{\text {MAIN ind }}$ & $\begin{array}{r}0.0047 \\
{[0.003]}\end{array}$ & $\begin{array}{r}-0.0065 \\
{[0.005]}\end{array}$ & $\begin{array}{c}0.0091^{* *} \\
{[0.004]}\end{array}$ & $\begin{array}{r}0.0105 \\
{[0.007]}\end{array}$ & $\begin{array}{l}0.0169^{* * *} \\
{[0.006]}\end{array}$ & $\begin{array}{r}-0.0075 \\
{[0.005]}\end{array}$ \\
\hline$c f_{\text {MAIN ind }}$ & $\begin{array}{r}-0.0043 \\
{[0.017]}\end{array}$ & $\begin{array}{r}0.0448 \\
{[0.028]}\end{array}$ & $\begin{array}{r}-0.0132 \\
{[0.023]}\end{array}$ & $\begin{array}{r}0.0141 \\
{[0.029]}\end{array}$ & $\begin{array}{r}-0.0183 \\
{[0.031]}\end{array}$ & $\begin{array}{r}0.0545 \\
{[0.038]}\end{array}$ \\
\hline $\ln \left(A_{\text {MAIN ind }}\right)$ & $\begin{array}{l}0.0152^{* * *} \\
{[0.003]}\end{array}$ & $\begin{array}{r}0.0045 \\
{[0.005]}\end{array}$ & $\begin{array}{l}0.0180^{* * *} \\
{[0.004]}\end{array}$ & $\begin{array}{c}0.0102^{*} \\
{[0.006]}\end{array}$ & $\begin{array}{r}0.0019 \\
{[0.005]}\end{array}$ & $\begin{array}{r}0.0040 \\
{[0.006]}\end{array}$ \\
\hline \# of obs & 146,128 & 68,842 & 77,286 & 51,455 & 50,533 & 44,140 \\
\hline$R^{2}$ & 0.095 & 0.024 & 0.099 & 0.089 & 0.109 & 0.106 \\
\hline \# of firms & 24,904 & 18,613 & 13,904 & 9,679 & 7,841 & 7,384 \\
\hline Firm FE & YES & YES & YES & YES & YES & YES \\
\hline Year FE & YES & YES & YES & YES & YES & YES \\
\hline
\end{tabular}


for the full sample reported in the first column, the coefficient on the SME-exchange industry $q$ is negative but insignificant. The main-board industry q also has an insignificant coefficient, suggesting that the contemporaneous correlations we observe in the preceding analysis are not reversed during the next year.

To further detect possible reversal, we estimate the lead-growth regression within sub-samples. Between the small vs. large private-firm sub-samples (reported in the second and third columns), we find no evidence of reversal in the correlation in the small-firm sub-samples, for which we observe a particularly strong contemporaneous correlation between the SME-exchange industry $q$ and private-firm growth. In fact, the correlation in this sub-sample remains positive (albeit insignificant), which further refutes the notion of reversal. With the sub-samples sorted by industry growth, we again find no evidence of reversal. Specifically, as shown in the sixth column of $<$ Table 6>, the high-growth-industry sub-sample, in which a strong contemporaneous correlation has been observed, still shows a positive (albeit insignificant) correlation between the SME-exchange industry $q$ and the leading private-firm growth.

To ensure the robustness of our results, we lead the private-firm growth by two years (results not tabulated). This time, the full-sample estimation yielded a significant and negative coefficient on the SME-exchange industry q. However, the smallfirm and the high-growth-industry sub-samples continued to show an insignificant coefficient on the q ratio. All in all, there is no evidence that the contemporaneous correlation between the SME-exchange industry $q$ and private-firm growth is reversed subsequently.

\subsection{Comovement among Private Firms and Aggregate Volatility}

In this section, we examine whether private firms comove in relation to the SME exchange prices and this comovement contributes to the aggregate volatility of private firms as a whole. To this end, we utilize the number of SME-exchange listings from an industry. The idea is as follows. Suppose that our measure of the SME exchange stock prices in the preceding analyses-i.e., the Tobin's q ratio averaged over the SME exchange-listed firms in an industry-is indeed affected by industry-wide misinformation. Suppose further that the industry-wide misinformation is the reason for the average q's positive correlation with private-firm growth. If so, then the number of SME-exchange listings would directly measure how many companies are subject to such industry-wide misinformation and thus how severely the average $q$ ratio is contaminated by the industry-wide noise. With more SME exchange-listed firms within industry, the average $q$ would contain less firm-specific factors and more industry-wide ones, the latter of which are assumed to be noise. Under this scenario, 
we would then see private firms in an industry comove more and fluctuate more as a group, the more public companies are under the industry-wide noise and the more prevalent is the noise within industry.

To evaluate this scenario, we first examine the degree of comovement among private firms in relation to the SME-exchange listings by estimating the following equation:

$$
\operatorname{disp}_{i, t}=\alpha_{i}+\sum_{\substack{k=S M E, \\ \text { MAlN, } \\ \text { private }}} \ln \left(n_{-} \text {firms }\right)_{k, i, t-1}+c f_{i, t-1}+\ln \left(A_{i, t-1}\right)+i_{i}+y_{t}++\varepsilon_{i, t}
$$

where $\operatorname{disp}_{i, t}$ is the cross-sectional dispersion in the asset growth rates among private firms in industry $i$ during year $t$. The dispersion is measured either by the crosssectional standard deviation of individual private firms' growth rates within industry (disp1), or by the difference between the $95^{\text {th }}$ and the $5^{\text {th }}$ percentiles of the growth rates (disp2). The main regressor is the log number of the SME exchange listings from industry $i\left(n_{-} f i r m s_{S M E}\right)$, and we additionally include the log numbers of the mainboard listings and of private firms in the industry ( $n_{-}$firms MAIN $_{\text {and }}$ anfirms private, respectively). We also control for the equally weighted cash flows of private firms and their equally weighted firm size in log. Finally, we include both industry fixed effects (i) and year fixed effects $(y)$.

The cross-sectional dispersion measures contain some extreme values. Thus, when regressed on the log number of the SME-exchange listings and control variables, the $\mathrm{R}$-squared is even lower than 1\% (not tabulated). We thus transform the two dispersion measures either by winsorizing or by truncating, both at the 1- and 99-percentile levels.

The results with the winsorized measures are reported in the first and second columns of $<$ Table $7>$. It is shown that the log number of the SME exchange listings is negatively related to both measures of dispersion. That is, as an industry has more SME-exchange listed firms, private firms within the industry become more similar to each other in terms of their growth profile. Or equivalently, the result indicates the existence of a strong industry-wide factor whose influence on private firms increases with the SME-exchange listings. However, the coefficients are statistically significant only at the $10 \%$.

The third and fourth columns of the table show that the statistical significance of this negative association improves when the dependent variables are truncated instead of being winsorized. Specifically, the cross-sectional standard deviation (disp1) is now related to the log number of the SME-exchange listings at the $1 \%$ level, while 
the difference between the $95^{\text {th }}$ - and the $5^{\text {th }}$-percentile growth rates (disp2) shows significance at the $5 \%$ level.

Interestingly, across the two specifications and the two different dispersion measures, the coefficient on the log number of main board listings is insignificant. One can infer from this finding that an industry-wide factor and its impact on private firms are not related to the main-board listings. Indeed, the coefficients on the SMEexchange listings and on the main-board listings are consistent with our earlier finding that the industry-specific economic fundamentals are better reflected in the SME exchange stock prices than in the main board stock prices.

Finally, we examine the aggregate volatility of private firms. To this end, we sum the total assets of all private firms in a given industry and each year compute the growth rate of those industry-wide aggregate assets of private firms. The resulting annual growth rate is the dependent variable of this analysis. We use the same set of regressors as those in Eq. (3).

\section{〈Table 7〉 Panel Regressions of Private-Firm Comovement on SME-Exchange Listings}

The table reports industry-year panel regressions. The dependent variable is a measure of cross-sectional dispersion in the growth rate of private firms within industry (disp 1 or disp2), or a measure of aggregate volatility of private-firm growth within industry ( $\mathrm{AggVol}$ private). The regressors are detailed in Section 5.2 (below Eq. (3)). Numbers in brackets are the cluster-robust standard errors. ${ }^{* * *}$, and ${ }^{* * *}$ indicate the statistical significance at the $10 \%, 5 \%$ and $1 \%$ levels, respectively.

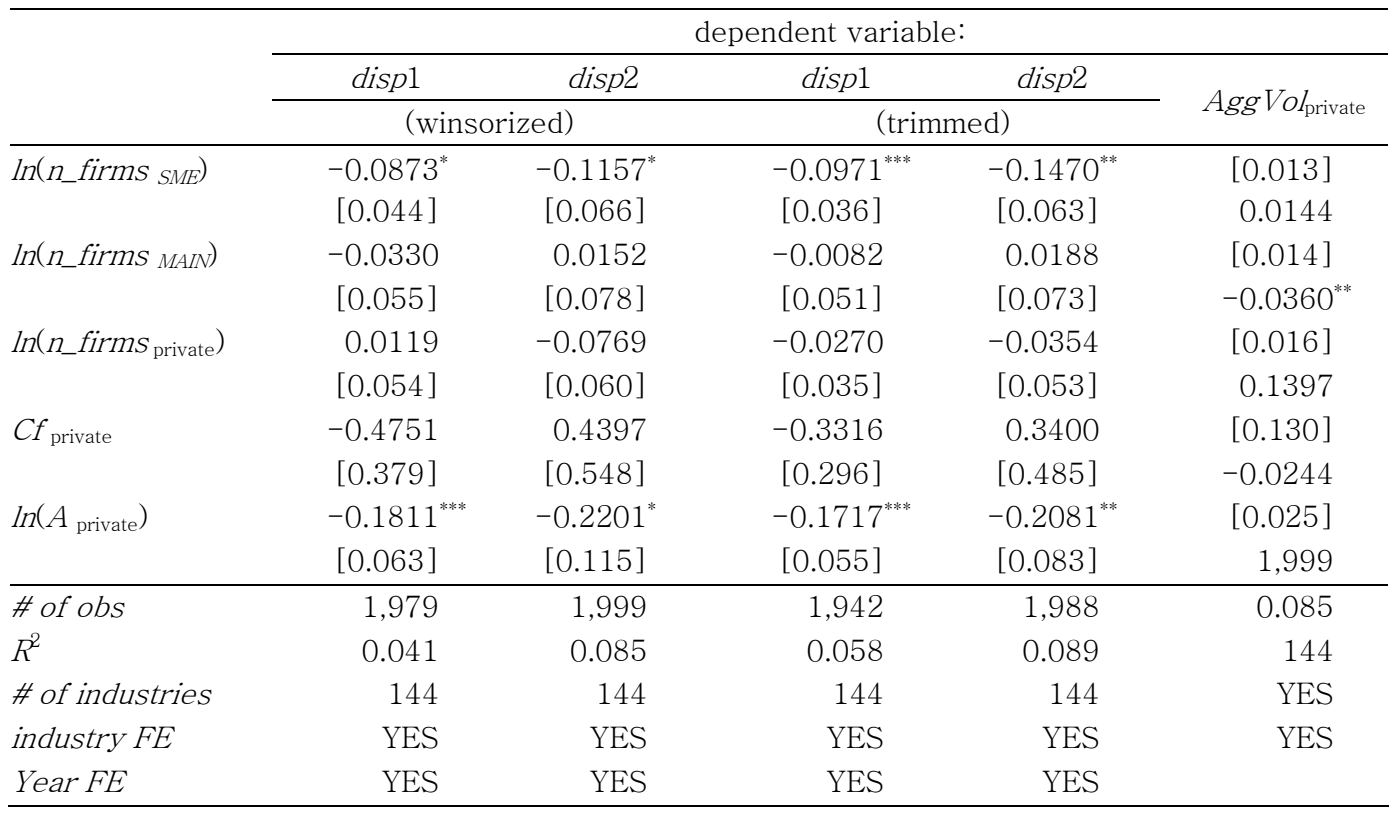


The last column of $<$ Table $7>$ shows that there is no positive relation between the log number of SME-exchange listings and the aggregate volatility of private firms. The coefficient is far from being significant, both economically and statistically. Of all the regressors, only the log number of private firms enters the regression with a significant coefficient. For this regressor in particular, the coefficient is negative, suggesting that there is a diversification effect across private firms within industry.

\section{Conclusions}

Using data from Korea, this paper shows a positive correlation between the SME exchange stock prices-aggregated to the industry level and in the form of a q ratioand private-firm growth. The paper also shows that the correlation is particularly pronounced for the growth of small-size private firms and those in growing industries, especially when the growth is funded by equity. In all those results, the correlation between the main board stock prices and private-firm growth is explicitly controlled for. Our results thus suggest that the SME exchange in Korea augments the country's main board as a growth market by capitalizing the type of industry growth opportunities that are not readily captured by the main board stock prices.

While our results are from a single country, it is a country that is widely considered to have developed the example of a successful SME exchange. Thus, when Korea is cited as a place where the SME exchange is properly functioning, our paper offers descriptive evidence for that.

The paper provides a broader implication as well. Policymakers and practitioners constantly mention the conflict between SMEs' financing needs and stock-market investors' demands for high-quality public equities. An SME exchange is thus, it is then argued, torn between two opposing responsibilities, namely, to be a prolific financing vehicle and a prudent bastion of investor protection. Our results imply that a reconciliation between the two responsibilities is not impossible. As shown in the paper, when more companies belonging to a growing sector are listed on the SME exchange, the exchange's stock prices-when aggregated up to the industry level-become more informative about the industry's growth opportunities. This should be beneficial to stock-market investors as well as to the companies. No doubt some of those listed companies may well be "low-quality" firms and thus invite "speculators" to the market. However, those speculators - and their pursuit of an informational edge in particular-are precisely what makes the stock market informationally efficient. To the extent that those speculative spirits are directed toward the sector as a whole and its economic fundamentals, the SME exchange can be a place where valuable information is generated and both companies and investors can benefit from it. 


\section{References}

Abel, A. B. and J. C. Eberly, 2011, How Q and cash flow affect investment without frictions: An analytic explanation, The Review of Economic Studies 78 (4), pp. 1179-1200.

Alderighi, S., S. Cleary, J. Irving, and J. Woodsome, 2017, Small and medium-sized enterprises and SME exchanges, World Federation of Exchanges and Milken Institute joint report.

Asker, J., J. Farre-Mensa, and A. Ljungqvist, 2012, What Do Private Firms Look like?, Unpublished Working Paper.

Asker, J., J. Farre-Mensa, and A. Ljungqvist, 2015, Corporate Investment and Stock Market Listing: A Puzzle?, Review of Financial Studies 28 (2), pp. 342-390.

Ayyagari, M., T. Beck, and A. Demirguc-Kunt, 2007, Small and medium enterprises across the globe, Small Business Economics 29, pp. 415-434.

Ayyagari, M., A. Demirguc-Kunt, and V. Maksimovic, 2011, Small vs. young firms across the world: Contribution to employment, job creation, and growth, Unpublished Working Paper.

Badertscher, B., D. M. Shanthikumar, and S. H. Teoh, 2017, Private Firm Investment and Public Peer Misvaluation, Unpublished Working Paper.

Badertscher, B., N. Shroff, and H. D. White, 2013, Externalities of public firm presence: Evidence from private firms' investment decisions, Journal of Financial Economics 109 (3), pp. 682-706.

Beck, T. and A. Demirguc-Kunt, 2006, Small and medium-size enterprises: Access to finance as a growth constraint, Journal of Banking and Finance 30 (11), pp. 2931-2943.

Binh, K., J. Park, and K. Eom, 2016, The effect of listing switches from a growth market to a main board: An alternative perspective, Unpublished Working Paper.

Carpentier, C., J. F. L'her, and J. M. Suret, 2010, Stock exchange markets for new ventures, Journal of Business Venturing 25 (4), pp. 331-438.

Carpentier, C., J. F. L'her, and J. M. Suret, 2012, Seasoned equity offerings by small and medium-sized enterprises, Small Business Economics 38 (4), pp. 449-465.

Chan, K., L. Chan, N. Jegadeesh, and J. Lakonishok, 2006, Earnings Quality and Stock Returns, Journal of Business 79 (3), pp. 1041-1082.

Chen, H. and S. Chen, 2012, Investment-cash flow sensitivity cannot be a good measure of financial constraints: Evidence from the time series, Journal of Financial Economics 103 (2), pp. 393-410.

Fazzari, S., R. Hubbard, and B. Petersen, 1988, Financing constraints and corporate investment, Brookings Papers on Economic Activity 1, pp. 141-195. 
Gerakos, J., M. Lang, and M. Maffett, 2013, Post-listing performance and private sector regulation: The experience of London's Alternative Investment Market, Unpublished Working Paper.

Hayashi, F., 1982, Tobin's marginal q and average q: A neoclassical interpretation, Econometrica 50 (1), pp. 213-214.

Jung, C., D. Lee, and K. Park, 2009, Can investor heterogeneity be used to explain the cross-section of average stock returns in emerging markets? Journal of International Money and Finance 28 (4), pp. 648-670.

Kaplan, S. and L. Zingales, 2000, Investment-cash flow sensitivities are not valid measures of financing constraints, Quarterly Journal of Economics 115 (2), pp. 707-712.

Morck, R. and B. Yeung, 2011, Economics, history, and causation, The Business History Review 85 (1), pp. 39-63.

Tobin, J., 1969, A general equilibrium approach to monetary theory, Journal of Money, Credit, and Banking 1 (1), pp. 15-29.

World Federation of Exchanges, 2016, WFE report on SME exchanges. 


\section{코스닥시장의 “성장시장”으로서의 역할 분석: 코스닥시장 주가와 비상장기업 성장의 상관관계를 중심으로"}

최 희 정 (국민연금연구원 부연구위원)

이 동 욱(고려대학교 교수)**

<요 약>

본 논문은 코스닥시장이 혁신기업의 성장을 지원하는 “성장시장” 으로서의 역할을 수행하고 있는지를 분석한다. 특히, 혁신의 주체가 될 성장산업의 성장잠재력을 코스닥시장의 주가가 제대로 반영하고 있는지를 고찰한다. 이를 위해, 한 산업의 성장잠재력을 산업 내 비상장기업들의 성장률을 통해 구하고, 이들이 동종업계 코스닥기업들의 주가와 양의 상관관계가 있는지를 분석한다. 1999년부터 2015년까지의 기간 동안, 코스닥시장 주가와 비상장기업 성장 간에는 양의 상관관계가 존재하는 것으로 발견되었다. 그리고 이러한 상관관계는 비상장기업의 규모가 작은 경우, 비상장 기업이 고성장산업에 소속되어 있는 경우, 그리고 비상장기업 성장을 위한 자금조달이 자기자본 (주식)으로 이루어지는 경우에 더 강한 양의 값을 가지는 것으로 관찰되었다. 주목할 점은, 동일 회귀분석 내의 KOSPI시장 주가는 상반된 모습을 보인다는 것이다. 구체적으로, KOSPI 주가와 비상장기업의 상관관계는 비상장기업의 규모가 큰 경우, 비상장기업이 저성장산업에 속하는 경우, 그리고 비상장기업 성장을 위한 자금조달이 타인자본(부채)으로 이루어지는 경우에 더 뚜렷하였다. 결론적으로, 코스닥시장은 산업 전체의 성장잠재력 중 $\mathrm{KOSPI}$ 시장이 반영하지 못하는 정보를 주가에 구현함으로써 $\mathrm{KOSPI}$ 시장과 상호보완적인 “성장시장” 으로서의 역할을 수행하는 것으로 파악된다.

핵심 단어: 코스닥시장, 비상장기업, 산업, 성장잠재력, 한국 주식시장

JEL 분류기호: G14, G31, G32

* 본 논문은 "Stock prices of public firms and their spillovers on privately held companies: Evidence of negative externalities"와 "Small-size public companies and industry aggregate fluctuations"의 제목으로 회람되었던 논문의 수정본으로서 최희정 박사의 고려대학교 박사학위 논문에 기반하고 있습니다. 이동욱 교수는 고려대학교 아시아 지배구조 연구소(AICG)와 고려대학교 경영대학(KUBS)의 연구비지원에 감사드립니다. 본 논문은 2015년도 정부(교육부)의 재원으로 한국 연구재단의 지원을 받아 수행되었습니다(NRF-2015S1A5A2A01013715).

** 연락담당 저자, 주소: 서울특별시 성북구 안암로 145 고려대학교 경영대학 02841;

E-mail: donglee@korea.ac.kr; Tel: 02-3290-2820; Fax: 02-3290-5394. 